ISSN 0819-2642

ISBN 9780734037336

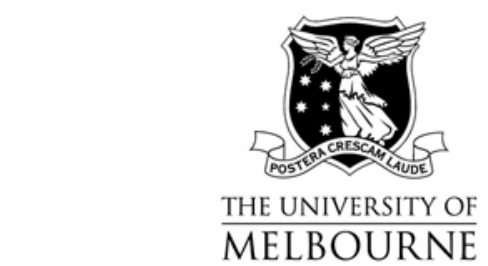

THE UNIVERSITY OF MELBOURNE

DEPARTMENT OF ECONOMICS

RESEARCH PAPER NUMBER 1023

December 2007

100 Years of Tariff Protection in Australia

by

Peter Lloyd

Department of Economics

The University of Melbourne

Melbourne Victoria 3010

Australia. 


\title{
100 Years of Tariff Protection in Australia
}

\author{
Peter Lloyd \\ University of Melbourne
}

Short running title: 100 Years of Tariff Protection in Australia

Address for Correspondence:

Department of Economics,

University of Melbourne,

Parkville, Vic. 3010,

Australia

Phone: 61383445291

Fax: 61383446899

Email: pjlloyd@unimelb.edu.au

Acknowlegements: I would like to acknowledge helpful comments on an earlier draft from Robert Dixon, Jonathan Pincus, Donald MacLaren and Robert Wells, and the ABS for providing data. Robert Dixon also provided great assistance in managing Excel files. 
100 Years of Tariff Protection in Australia

This paper presents time series of tariff rates in Australia from the time of Federation. As a preliminary to the construction of economy-wide series, it constructs series for three broadly representative goods throughout the 100 years; passenger motor vehicles, blankets and beer. It then constructs two economy-wide series, one for all imports and another for dutiable imports only. It discusses the main events relating to turning points in the series and concludes with some applications.

JEL classification codes: F1, N6, N7

Keywords: protection, tariff rates, Australia, 
From the time of Federation to the present tariffs have been a contentious issue in Australian political life. They have occupied as much time in parliamentary debate as almost any other topic and they have from time to time occasioned much debate among the general public. The reason underlying this debate is that an increase in any tariff will raise the real income of some Australian households (for example, owners of capital and workers employed in the industry affected) and lower the real income of other households (notably consumers and business buyers of the products). I shall not examine the economics or the political economy of this history in this paper, except for some brief comments in the final Section. My task is the much more humble one of constructing economically meaningful and economy-wide time series of the average tariff rate covering imports of goods into the country.

The problem of measuring the average height of tariff barriers has long been recognised in Australia. There is an honourable history of attempts to construct series of average tariff rates in both the academic and government domains.

From the time the first Customs Tariff Act passed in 1902, statistics of duties collected and the value of imports have been compiled by the Government Statistician. For the years 1903, 1904 and 1905 data on imports and duty collected were compiled by the NSW Government Statistician under instructions from the Commonwealth Minister of Trade and Customs. The first two years were done by T. A. Coghlan, the pioneer of many statistical series in NSW and Australia. The statistics of duty collected give a division between free and dutiable imports.

The first official calculation of an average duty was published in the Yearbook of the Commonwealth of Australia 1908 (Commonwealth of Australia, 1908, p. 524). This reported two statistics of the average rate of import duty for the year 1906. One was the average rate of duty on all merchandise, dutiable and free. This expressed the total duty collected on all goods as a percentage of the total value of the imports. The duties included specific as well as ad valorem rates of duty. For the year ended 1906, the rate 
was 17.5 per cent. This method of averaging implicitly uses current import weights. The index is a Paasche index.

The Commonwealth Statistician also calculated the rate on all "dutiable imports” only, excluding imports that enter duty-free. This gives a much higher rate, 27.14 per cent in 1906. This second statistic recognised a problem in that the duty on all imports includes both imported goods that are competitive with Australian outputs and non-competitive inputs used mainly in the production of these outputs. Duty-free admission was due mainly to the practice of admitting goods duty-free if they were not competitive with Australian-produced goods. The Customs Tariff 1902 introduced 'special exemptions” from duty which are the ancestors of the later by-law system and the present day concessional import system. 35.18 per cent of all goods by value entered duty-free in 1906.

In later years, Commonwealth Yearbooks have reported these two average rates. However, the reporting has been sporadic and has not used a consistent definition with respect to the coverage of commodities and duty collected and the valuation of imports.

Vamplew (1987, series GF 357) compiled long terms series of customs revenue and value of imports. Athukarola and Chand (2007) have used them to construct a series of average tariff rates for the period 1870 to 2002. However, the Vamplew historical series of customs revenue does not agree with the official series; they appear to be gross of refunds and drawbacks, make no adjustments for revenue duties and valuation changes, and may include excise duty on all exciseable goods.

Crawford (1934) and Carmody (1952) constructed separate indices for goods entering at General and at BP rates. Crawford (1934, p. 216) held the view that "It follows of course that the General Tariff Levels and Preferential Tariff Levels cannot be directly compared for the composition of imports coming in at General Tariff rates is considerably different from that subject to the Preferential Tariff.” Carmody concurred. Their indices are Laspeyres indices. Carmody chose consumption weights because “... it must be stated unequivocally that at no time can imports of each commodity be used as weights. If actual imports are used, the anomalous result is obtained that as any particular duty is increased relatively to others the imports of the commodity concerned will probably fall, 
proportionately to others, and the weight given to the rising duty in the index is diminished, possibly to zero.” (Carmody,1952, p. 57) This followed the view in the influential report of the League of Nations (1927). These problems of choosing nonpreferential and/or preferential rates and weighting different tariff items were considered by others, such as Corden (1963) and the Vernon Committee (1965, Vol. II, Appendix L). They were not, however, resolved.

For the period after the Second World War, there is another problem in that the Australian Government has, from time to time, assisted some industries by means of nontariff measures as well as tariffs. In 1939 the Australian Government introduced import licensing. These quantitative restrictions were continued after the War and other nontariff instruments were introduced; for example, the automobile content plan was a part of the agreement reached in 1945 between the Australian Government and General Motors Holden to promote the local production of chassis and engines. Quotas and tariff quotas continued to be used selectively until the last were abolished on automotive and TCF products in 1988 and 1993 respectively.

Beginning with the year 1968-69, the Tariff Board and later its successors, the Industries Assistance Commission, the Industry Commission and the Productivity Commission (hereafter referred to as TB/IAC/IC/PC) have produced annual estimates of the nominal and effective assistance for the Manufacturing Sector. This sector accounts for 90-95 per cent of total imports in the period after the Second World War. These estimates include assistance from the principal ntms as well as tariffs. Unfortunately, it is not possible to construct series including the effects of ntms for the period before 1968-69. For long term series we must revert to measuring average tariffs. Outside the 20-year period of comprehensive import licensing from 1939 to 1960, tariffs have provided the bulk of the protection for Australian import-competing producers.

Section I examines the problems of measurement due to the presence of preferences. As a preliminary to the construction of economy-wide series, it examines the history of protection of three broadly representative goods throughout the 100 years; passenger motor vehicles, blankets and beer. These series identify other measurement problems such as the treatment of tariff on goods which are subject to excise taxes when produced in Australia. They are of interest to economic historians for their own sake. Section II 
considers the choice of an index formula to measure the average and the problem of measuring the tariff rates on exciseable goods. Both of these Sections use recent advances in trade theory to elucidate the choices. Guided by the insights of the previous sections, Section III constructs two 100-year times series covering all imports. These measure the average levels of protection in the Australian economy over the period. Some applications on these series are commented upon in Section IV.

For most of the past 100 years Australia has had a multi-column Customs Tariff, that is, for each tariff item there are columns showing the rate applied to imports from the relevant sources. From 1901 to 1908 there was only one column. From 1908 to 1937 there was a two-column Tariff, one column for the General rate and one showing the British Preferential (BP) rate. For any item, the BP rate was equal to or less than the General rate. In 1937 an Intermediate rate column was introduced for the countries to which Australia was obliged to grant MFN treatment or which granted Australia MFN treatment for its exports, and to British Empire countries that did not qualify for the BP rate. For some items, the Intermediate tariff rate was strictly between the higher General rate and the lower BP rate, hence the name. For other items, the Intermediate Tariff rate was equal to the General rate. This Intermediate column became the dominant column in terms of actual imports as the list of countries covered was extended until it covered all non-BP countries except Japan and Bahrain. When the Trade Treaty with Japan was signed in 1965 the column was removed. The Customs Tariff reverted to a single column in 1980 with the end of British Preferences. In addition, there were preferential rates for goods subject to Primage duties for almost all of the period these duties applied.

In addition to the preferences recorded in the first and second columns of the Schedule in the Customs Tariff, preferences were given to other countries or groups of countries for various intervals during the 100 years. The very first preferences adopted in the Commonwealth were those to South African exporters under the Customs Tariff (South African Preferences) Act 1906. From 1965, coincidentally the year in which tariff discrimination against Japan and the Intermediate Tariff was ended, (non-reciprocal) preferences were granted to Less Developed Countries and in 1965 also, to New Zealand under the Australia Free Trade Agreement (NAFTA). NAFTA was the first of the post- 
Second world war bilateral preference agreements. Since the 1990s preferences have proliferated as Australia has signed bilateral trade agreements with Singapore, Thailand and the USA.

I ignore all preferences other than British preferences in my calculations of rates for individual commodities because the other preferences schemes only applied for short periods and were quite restrictive in their coverage (except for those to New Zealand under the 1983 CER Agreement). Thus I shall record and compare BP rates and (nonpreferential) MFN rates. For the period when Intermediate tariff rates applied to some tariff items (1937 to 1965) a choice has to be made, for items where the two rates differ, between the General and the Intermediate rate. As the Intermediate rate is the MFN rate insofar the MFN principle was observed in the pre-GATT days, I shall use this rate. For brevity a series combining General and MFN or Intermediate and MFN rates, as called for, is referred henceforth to as an "MFN" series.

For those years for which there were imports at both MFN and at lower BP rates, a choice has to be made. Should we use the MFN rates or the BP rates or some average of the two? The solution of two separate series adopted by Crawford and Carmody is unsatisfactory as the products imported under different rates are clearly closely related.

In the presence of multiple rates for one tariff item, international trade economists have usually argued that one should select that rate which is the "marginal rate", that is, the rate at which buyers decide the quantity of imports. If the products imported, for some tariff item, under the MFN and the BP rates were truly homogeneous, only one of these rates could be the marginal rate. However, the continued importation of products at different rates indicates the products are differentiated. Modern cge models, such as the Monash and GTAP models, model this differentiation using the Armington assumption that products of an industry are differentiated nationally. There are other models in modern trade theory that explain national product differentiation in terms of product characteristics linked to differences among nations in technologies or endowments or scale of outputs. With the advent of these theories, it is now accepted that products coming from different sources are usually differentiated. If the products from different sources are differentiated, both the MFN and BP rates can be marginal rates. 
Hence, we need to average the different rates applying to an item with multiple rates. The next sub-section tests the possible methods by constructing average series for three individual sample commodities.

\section{Time series for individual goods}

This sub-Section reports the construction of 100-year time series for three commodities; passenger motor vehicles, blankets and beer. These three commodities are illustrative of the time path of protection over the history of the Australian Federation, and they also illustrate the problems of constructing consistent time series.

To construct a consistent long-term time series for a commodity we require a commodity which can be identified as a distinct commodity, and which can be traced in the statistics of customs taxation and imports over the whole period. Many commodities in the current commodity classifications have either not been present in earlier classifications or have been present throughout the 100 years but have at some time been split into multiple subcommodities with different tax rates or they have been combined with other items. The three commodities selected satisfy these requirements.

The three goods selected are useful illustrations. Passenger motor vehicles have been a major item of household (and business) expenditure and have been one of the most highly protected product groups for much of the 100 years. Blankets are an example of a product group from within the Clothing, Textile and Footwear group, another product group that has been highly protected for much of the 100 years. Both of these have been an identifiable tariff item or set of items throughout the period. Blankets are one of the few CTF product groups that have been subject to ad valorem tax rates throughout the period, making it much easier to trace its history. On the other hand, beer has always been subject to specific customs duty rates and it is also a commodity that, when locallyproduced, is subject to excise taxation. Hence, the construction of a series for this commodity illustrates both the problem of converting specific duty rates to ad valorem equivalents and the interaction with the excise taxation system.

Tables 1, 2 and 3 report series for the three commodities. Sources and notes on the construction of these series are provided in Appendices 1 and 2. In particular, the 
adjustment for the change in the method of valuing imports made in 1947 changes the shape of the graphs (see Section III below). For the years 1902-03 to 1946-47, this adjustment flattens the series by lifting the commodity rates in the period up to 1929-30 by 10 per cent and then reducing the higher rates during the depression and war years 1931-32 to 1946-47.

\section{Passenger Motor Vehicles}

In the case of Passenger Motor Vehicles, I look only at fully-assembled vehicles for passenger transport. (The rates of protection for parts and components are different.) "Motor cars" were first identified as a separate product group in the Customs Tariff 1908; prior to that they were a part of a general group of "vehicles” ("barouches, broughams, landaus, Victorias, mail Phaetons, drags and similar vehicles”), most of which were not motorised. The rates are those applying to new vehicles. Second-hand vehicles have also had tariffs imposed on them in order to prevent the importation of second-hand vehicles from undermining the protection of new vehicles produced in Australia, usually at the same rates as those applied to imported new vehicles.

From the time of the first Australian Customs Tariff, passenger motor vehicles have been subject to an ad valorem tariff. The rates have been consistently above the average for all goods.

Column (3) in Table 1 reports the series of statutory tariff rates on imports from MFN sources. This is the basic series. There were two periods of peak rates; from 1920-21 to 1946-47 the ad valorem MFN rate was 55 per cent, after which it fell and then rose again to the peak level of 57 1/2 per cent over the period 1978-79 to 1987-88.

In 1907 a preference was introduced for imports of motor cars sourced from the United Kingdom. A British Preferential (BP) rate of duty which was lower than the General (later the MFN) tariff rate on goods imported from non-preferential sources persisted until the British Preferential rate for this tariff item was eliminated in December 1974. Over other intervals, imports of passenger motor vehicles sourced from non-MFN and non-BP countries have also entered at a rate lower than the MFN rate, usually at a rate somewhere between the lower BP and the higher MFN rate. However, for Passenger 
Motor Vehicles, the only two rates that have applied to significant quantities of imports have been the BP rate, when it existed, and the MFN rate. Column (2) of Table 1 reports the series of BP rates. Figure 1 graphs the ad valorem MFN and BP rates applied to this product group for every year since 1901.

In Column (4) of Table 1 I have constructed the average duty paid on this product group. For the earlier sub-period 1908 to 1957-58 when BP rates applied to imports sourced from Great Britain, I have used the mid-point between the BP rate and the MFN rate. In this period, imports of motor vehicles came predominantly from Great Britain with some from the US and European countries. For the sub-period 1958-59 to 1973-74, I have used the import-weighted average. 1958-59 is a natural breaking point as both rates were decreased and the import-weighted average in that year is almost equal to the mid-point. Thereafter imports from MFN sources, especially Japan, became much more important. The import-weighted average is above the mid-point. There is some annual variation because of the variation in sources. But it converges steadily towards the higher MFN rate, reflecting the increasing consumer preferences for imports from these sources.

This series of the average rate on imports from all sources follows the series for the MFN rate quite closely. Like the latter series it has two peaks; 52.5 per cent (= the mid-point of MFN and BP rate + 7.5 per cent Primage duty) over the period 1931-32 to 1946-47, and 57.5 per cent (=MFN rate) over the period 1978-79 to 1987-88. (The peak of 55 per cent in the single year 1931-32 is due to the fact that there was no preferential Primage rate for goods sourced from the UK in the first two years of Primage duties.)

A final series is reported in the last column of Table 1 and graphed in Figure 2. This includes the adjustment for the method of valuation. The adjustment changes the series for the years 1901-2 to 1946-47. The adjusted series still has two peaks but the date of the first peak is shifted to the earlier years of 1920-21 to 1929-30. The unadjusted rate for this period is 45 per cent but the adjusted rate is 49.5 per cent.

\section{Blankets}

Blankets too have been subject to above-average rates of protection throughout the last 100 years. 
The MFN rates levied on this product peaked at 55 per cent over the three years 1932-33 to $1934-35$ and again at 50 per cent in 1982-83. The rate has declined steadily since the second peak.

A British Preferential rate lower than the General rate was first introduced for Blankets in the Greene Tariff of 1908, the same time as the split into rates for two sources for Passenger Motor Vehicles, but the lower BP rates was eliminated in 1980, some six years after the end of British preferences for Passenger Motor Vehicles. Preferences for groups of countries other than the UK are more important than in the case of Passenger Motor Vehicles but they are not reported here. Figure 3 graphs the MFN and the BP tariff rate series.

As with Passenger Motor Vehicles, I have calculated a series for imports of Blankets from all sources, after adjustments for BP rates and additional Primage duties, and then made a final adjustment for the change in the method of valuation in 1947. The adjusted and unadjsuted series have two peaks. The adjustment does not change the first peak for this commodity group but it does lower this peak rate from the unadjusted rate of 52.5 per cent to an adjusted rate of 46.2 per cent.

\section{Beer}

The time path of the nominal rate of protection for Beer has been different than that of the first two commodities.

Since Federation beer has been subject to import duty when imported and to excise duty when produced in Australia. (Until the classification based on the Brussels Tariff Nomenclature was introduced on July 1965 Beer was Item 1 in the Customs Tariff classification. It has always been Item 1 in the Excise Tariff classification.) The protection of Australian-produced beer is the difference between the tariff duty rate and the excise duty rate. As with Passenger Motor Vehicles and Blankets, imports of Beer sourced from the United Kingdom enjoyed a preference for a period. In the case of Beer, this period lasted from 1914 to 1977. 
The rate of protection of beer production is not transparent. There are two problems. First, one has to subtract the excise duty levied on the matching excise item. Second, both the excise tax and the customs tariff on beer are specific duties and one has, therefore, to calculate the ad valorem equivalent of the non-matching tariff duty. This is complicated by the fact that the base of the duties on beer changed from liquid volume to the alcohol content in 1988. Indeed, it takes a great deal of detective work to calculate the rates of protection on this commodity. Appendix 1 outlines the steps that have been taken and the sources.

For the first seven years the customs duty rate and the excise duty rate were the same. The Royal Commission on the Commonwealth Tariff in 1906 recommended a margin between the tariff and excise duty on all spirits to protect Australian manufacturers (Commonwealth of Australia, 1906). This was enacted in the Customs Tariff 1908 and a margin remained between the two rates until 1983.

I have been able to measure the rate of customs duty on Beer in ad valorem terms for the period. This is presented in column (4) of Table 3 and graphed in Figure 5. The series stops in 1980-81 because unit value statistics cannot be calculated beyond that date. Throughout the 100 years this rate has been high, always over 40 per cent and sometimes over 100 per cent.

But most of this rate is a duty to match the excise on the like product produced in Australia. I have also been able to measure the nominal rate of protection of Beer, defined as the difference between the customs duty and the excise duty, expressed in ad valorem equivalent terms, for the same period. Primage is added in the years it applied. (For details of the calculations, see Appendix 1.) This series of the nominal rate of protection is presented in column (5) of Table 3 and graphed in Figure 5. There is a second series in column (6) of Table 3 with the adjustment for the change in the method of valuing imports in 1947.

These time series for the nominal rate of protection for Beer differ from that for the other two commodities in two ways. 
First, there is much more year-on-year variability. This is due to the specific nature of the duty. Although the rates have been adjusted on average every two or three years, annual inflation in the price (unit value) of imported beer has meant that there are periods when the fixed duty combined with rising import prices has led to falling ad valorem equivalent rates of duty. This has been exacerbated by the fact that some adjustments were made to the excise duty or to the import duty without a corresponding matching adjustment to the other duty and, consequently, the margin of protection in dollar terms has shifted.

Second, looking at the general level of the nominal rate of protection, Beer has not been a heavily protected item for most of the 100 years. The highest nominal rates of protection were experienced in the decade immediately following the introduction of a difference between the excise and customs rates in 1908. At this time, the customs duty on imported bottled beer was hiked from 3d to 1 shilling and sixpence (an increase of 600 per cent), while the excise duty on beer remained at 3d. High tariff rates persisted over the decade from 1908 to 1918. For this period the rates without the adjustment for the change in the method of valuation of imports were in the 30 to 40 per cent plus range, despite the introduction of British Preferences for Beer in the Customs Tariff 1908. The rates with the adjustment for the change in the method of valuation were 10 per cent higher in this period.

This series of the nominal rate of protection shows a peak at 45.1 per cent for the unadjusted rates and 49.6 per cent for the adjusted rates, both in 1914-15. After that the ad valorem equivalent rate remained in the 10-20 per cent range for several decades. It declined steadily from the 1970s, both because of reductions in the margins between the specific customs and excise rates, and the reduction and then elimination of Primage on imported Beer. The rate returned to zero again in August 1983, shortly before the introduction of indexation of the rates.

This sample of three commodities shows it is possible to construct accurate and meaningful series of average tariffs for imports from different sources for each of these three sample commodity groups. However, it also shows that one needs to make adjustments for supplementary Primage duties, matching excise duties and changes in the method of valuation. 
The sample of three commodities illustrates the problem of constructing a single average statistic summarising the movement of tariff rates across all tariff lines s. Figure 7 brings the final series of average rates for each of the three commodities into one graph. Clearly, the three series have followed different paths and, in particular, the turning points are different for each of the commodities. (For this illustration, I have used the series before adjustment for the change in the method of valuation. The series with the adjustment behaves similarly.) These differences would hold $a$ fortiori if we had series for all commodities. Therefore, the choice of method to average these rates each year across commodities is going to determine the behaviour of the average.

This index number problem can be resolved using results from the theory of tariffs. Fortunately, a major breakthrough was made with the development of the concept of the Trade Restrictiveness Index (TRI) by Anderson and Neary (2005). The Trade Restrictiveness Index is the uniform tariff rate which yields the same utility as the differentiated structure of tariffs (and tariff equivalents if we can measure these for nontariff measures). It is a welfare-based measure. A second breakthrough was made when a group of economists at the World Bank (Kee, Nicita and Olarreaga, forthcoming) used a partial equilibrium form of the TRI to calculate the average tariff on imports for 88 countries in the 1990s. This is derived from the Harberger triangles measures of the welfare loss due to the tariff on each good. (This method is reviewed and extended in Lloyd and MacLaren, 2007.)

The first important lesson is that we should be averaging the nominal tariff rates (or more properly in the presence of subsidies and other ntms) the nominal rates of assistance, not the effective rates. The TRI is an average of the nominal rates but it does take account of all inter-industry effects arising from the use of imported inputs that have been subject to tariffs (assuming one has a general equilibrium model that specifies all of the intercommodity relationships in both supply and demand).

The second lesson is that weights should be import shares, not production or consumption shares. Since the time of the League of Nations (1927) study, it has been standard 
practice, in Australia and other countries, to object to the use of import weights on the ground that this practice understates the relative importance of goods subject to high tariffs.

While the objection is valid, it is not a fatal objection. The partial equilibrium form of the TRI is a mean of the tariff rates. The weights in this formula are import proportions multiplied by the elasticities of import demand (see Lloyd and MacLaren, 2007).

The third lesson relates to the choice of the mean statistic. Amazingly, this turns out to be the mean of order two, not the arithmetic mean (which is the mean of order one) or the geometric mean (the mean of order zero) favoured by the League of Nations (1927) and some others since that time. This choice of mean reflects the importance of the Harberger "square rule", that is, the loss of welfare due to a tariff is proportional to the square of the (ad valorem) tariff rate.

For the sub-period 1988-89 to the present, data on imports by tariff item and by source is available electronically from the ABS. For this sub-period, it is possible to construct a TRI series of average tariffs. It is also possible, for this sub-period, to remove the part of tariff duties on each exciseable good which merely match the rates of excise duty on the like product.

Figure 8 graphs the arithmetic mean tariff rate for all imports with and without the excise tax adjustment over the period 1988-89 to the end of the series in 2004-05. It also graphs the series of the TRI for tariffs in Australia (with the exclusion of matching excise duties on all exciseable goods) over this period. Table 4 reports the data. The excise-adjusted TRI is consistently above the excise-adjusted mean, as expected, because it uses the square of the ad valorem rates. The unadjusted arithmetic mean, the only series available for the whole period, lies between excise-adjusted mean and the excise adjusted TRI.

For the pre-electronic period, however, we do not have data on the aggregate value of imports of goods imported at different rates. Hence, we cannot calculate the TRI in place of the arithmetic mean for the whole 100 year period. Nor do we have data on the tariff revenue collected on exciseable goods as there is not an exact concordance (or rather a series of them) between excise duty and customs duty items. 
The only readily available alternative is an arithmetic mean obtained by dividing the revenue by the value of imports (total or dutiable only). ${ }^{1}$ This is an average of nominal rates and it uses import weights, as required. For the period after 1988-89, for which an excise adjusted average is available, the unadjusted series for all imports tracks the adjusted series very closely.

III

Compared to almost all other countries, we are fortunate in Australia in being able to put together reliable and consistent annual series of the customs duty collected and the value of imports starting from 1903, two years after Federation.

From this data, I have constructed two series of the import-weighted arithmetic mean tariff on Australian merchandise imports. One is the average tariff obtained from a series of the total duty collected divided by the value of all imports. The other is the total duty collected divided by the value of imports of goods on which duty has been paid (known in CBCS/ABS jargon as “Dutiable Clearances”). These two series are the only two series that can be calculated for the entire period.

However, the calculation of the two series is far from a simple matter of just transcribing the recorded values for each year and dividing. Adjustments need to be made to the duty collected series in some years for refunds and drawbacks of duties paid, duty collected on ships' stores and revenue duties. For the value of import series, adjustments need to be made before 1946-47 for changes in the method of valuation. The details of adjustments that have been made are stated in Appendices 2 and 3.

\footnotetext{
${ }^{1}$ Averages constructed in this way are Paasche indices with current period weights. The use of current period weights poses a problem in periods when the import shares change significantly. When this occurs, the average will change even if all the tariff item rates are constant. However, fixed base period weights also have problems as the import shares change over time and new commodities are introduced to trade. A Laspeyres index has to be rebased periodically.
} 
These series relate to customs duties only and do not, therefore, include calculation of the assistance due to non-tariff measures. However, the ABS-derived series of the average tariff does include anti-dumping, countervailing duties, and Primage duties where applicable. All of these are classified as para-tariffs and included in the definition of ntm's used by UNCTAD and the WTO. The series for dutiable imports only has excluded duty collected from the two revenue duties other than Primage that applied in the last 25 years because they were not protective. If this adjustment were not made, the series would be substantially distorted; the series fall sharply when a revenue duty was introduced and rise when the duty was abolished.

Both series include the whole of the duties levied on excisable goods. While the customs duty collected on these items should be adjusted to cover only the margin over the excise duty levied on like Australian-produced goods, this adjustment cannot be done (except for the period of electronic records from 1988-89). This is a significant weakness of the series which results in overstating the average duties.

The rates are the actual rates levied on imports; the series therefore combines MFN, preferential and concessional tariffs. They cover both final goods and intermediate and capital inputs. Throughout the period, Australian practice admitted duty free under bylaw and concessional import schemes those inputs that were not competitive with Australian-produced goods. Since the mid-1930s goods admitted duty free have been more than 40 per cent of the total value of merchandise imports (see column (6), Table 4). For this reason, the series of average duty on all imports has long been regarded in Australia as less useful than the series of the average tariff on dutiable imports only.

There is no definitive theoretical reason to prefer one series to the other. The weighting systems of both diverge from the ideal system of the TRI. Both series are reported.

There is a major break in the series related to the change in the method of valuing imports made in 1947-48. Prior to 15 November 1947, under the Customs Act 1901, all imports into Australia were valued at "British currency values”. But in practice Australian currency were accepted in payment of the duties (Nicholson, 1955, p. 221). Thus, the real tariff rates were lower than the apparent scheduled tariff rates. This was considered a 
disadvantage in tariff negotiations under the GATT, which Australia joined in the same year.

Three changes were made in the tariff system. (See House of Representatives, 1947, 1499-1500, 2143.) First, all goods were now valued in £A rather than £Sterling. Second, to compensate for the 25 per cent increase in value for duty from using the Australian currency values rather than British currency values, the 10 per cent margin was abolished. Thus the method of valuing goods for the purpose of duty was changed from $£$ Sterling fob plus 10 per cent to $£$ A fob. Third, all ad valorem rates were reduced by 12 per cent. To avoid awkward fractional rates of duty that would result from the application of the 12 per cent reduction, the reduced rates were adjusted to the nearest 2.5 per cent; for example, the MFN tariff rate on Passenger Motor Vehicles was reduced from 55 per cent to 47.5 per cent instead of $48.4(=55 \times 0.88)$ per cent. (The amount of duty collected from specific duties was unaffected by the new method of valuation.) These changes were supposed to leave the amount of duty collected unchanged or, in modern terms, to be revenue-neutral. ${ }^{2}$

In the Second Reading of the Bill to effect these changes, they were described by the Minister of Commerce and Agriculture as an "anomaly” and as being “...of an administrative character only” (House of Representatives, 1947, p. 1499). They are much more than that as the method of valuation affected the amount of tariff revenue collected and the levels of protection for almost 50 years. To an Australian writing in the $21^{\text {st }}$ century, the servility of the early Federation politicians in valuing imports in the currency of another country is astounding. It is even more astounding when one notes that all exports in official statistics were recorded in Australian pounds from 1901.

From the time of Federation until 1930-31 the pound sterling and the Australian pound were at parity and commercial rates of exchange were within 1 or 2 per cent of parity.

\footnotetext{
${ }^{2}$ We should remember that non-tariff measures, chiefly quantitative restrictions due to import licensing, became the binding constraint on imports of many items.

Although we cannot measure it, the average protection due to both tariff and nontariff measures almost certainly rose sharply in this period.
} 
The collapse of the gold standard in 1929 led Australia to devalue by 25 per cent vis-à-vis pound sterling in 1931. For the year 1930-31, $1.09 £$ A exchanged for $1 £$ Sterling and for the period from the following year until 1946-47, the last year in which this convention was used, the rate was $1.25 £ \mathrm{~A}$ for $1 £$ Sterling. ${ }^{3} \quad$ Consequently, for this period from 1930-31 to 1946-47, import values calculated on the basis of the pre-1947 convention are lower than those calculated using the post new convention.

These differences in the exchange rates necessitate an adjustment to the measured average tariff rates. To give a consistent series over the 100 years, I have expressed all tariff rates as the percentage rates that would yield the same duty under the current convention of valuing imports $£ \mathrm{~A}$ fob as the actual tariff rate did under the old convention. This means that all ad valorem customs duty and Primage duty rates and average rates for years before 1947 must be adjusted. Details of the method of adjustment are set out in Appendix 2. The two series before the adjustment are graphed in Figure 9 and the two series after the adjustment are graphed in Figure 10.

The series after the adjustments are the best available series. These graphs present the effects of 100 years of tariff-making in Australia on the time path of average levels of protection.

It is useful to look at the series chronologically and in particular to link major turning points of the series to Acts or events that significantly affect the series. General commentaries on the history of Australian tariffs have been given by a number of writers; see particularly, Brigden Committee Report (1929, Appendix A), Crawford (1968, A14:2) and Pincus (1995).

The initial Customs Tariff Act 1902 of the Australian Federation immediately established high tariff barriers for imports of many manufactured goods. These continued the high rates of duty imposed before Federation by Australian States individually. (Pincus, 1995

\footnotetext{
${ }^{3}$ These rates are calculated from the 100 year series of the bilateral exchange rate between the \$A and the £Sterling reported in the DX Databank.
} 
and Irwin, 2006 report average rates of duty in the States before Federation and discuss the transition from non-uniform State-based import duties to single Federal duties.)

The first important increase in rates was in the Customs Tariff 1908, commonly known as the Lyne Tariff following the convention of naming Acts after the Minister who introduced the bill to Parliament. This raised duties on many goods, particularly woollen goods, iron and steel and agricultural implements. However, the average tariff on dutiable goods increased by only a few percent, chiefly because the increase in rates was offset by the introduction of British Preferential rates. British preferences were extended to nearly all goods in the 1914 Customs Tariff.

There was a small downturn in the average in the years after 1917-18, partly due to the cessation of revenue duties levied during the First World War. This was followed by a steady increase in both series during the decade of the 1920s. The Customs Tariff 1921, known as the Greene Tariff, increased many rates, particularly on industries that had grown during the First World War. The Customs Tariff 1926 and 1928, known as the Pratten Tariffs, further increased many rates. During this period deferred duties were also introduced and the Customs Tariff (Industries Preservation) Act of 1921 led to the imposition of the first anti-dumping duties in Australia.

In the Great Depression period, the Scullin (Labor) Government raised some substantive rates and introduced a number of emergency duties between 1929 and 1931 which substantially increased protection. The increased rates were partly offset by extended preference margins to British goods after the Ottawa conference of 1932. However, the net effect was a large increase in the average tariff rate, indeed the largest in the 100 year series (see Figures 8 and 9). It is interesting to compare the series without and with the adjustment for the change in the method of valuation in these years. After the devaluation of the Australian pound in 1931 the rates after the adjustment are lower than the rates before the adjustment. Hence, one can regard some part of the increase in tariff rates during these years as an offset to the devaluation as the use of British currency for import values prevented the increase in value for duty that would have applied if instead, as is normal, Australian currency values had been used. 
There were some reductions in tariff rates between 1933 and 1939. These are reflected in the small decrease in average rates over this period.

The period leading up to and including the Great Depression is the pivotal period in the history of tariffs in Australia. It established high tariff barriers for the Manufacturing Sector overall. This is shown in my series as the average rate of protection is predominantly the average rate of protection of manufactured goods throughout the period. It also established firmly the feature that the Manufacturing Sector was the protected sector relative to the other sectors in the economy; the Agricultural, Mining and Service Sectors. This period established particularly high barriers for some Manufacturing industries. Although in the 1920 and 1930s a number of agricultural goods were protected by tariffs or an import embargo (sugar) and others by subsidies and marketing schemes (Brigden Committee, 1929, pp. 42-46), most subsidies and other assistance to agricultural producers date from after the Second World War. For the Agricultural Sector, recent evidence compiled by Anderson, Lloyd and MacLaren (2008) shows that the pattern of assistance discriminated against agricultural producers from the end of the Second World War until the 1990s.

These broad features of the tariff system persisted after the Second World War until the decade of the 1990s. The policy legacy of the Great Depression has lasted far beyond the business cycle effects.

The inter-industry pattern within the Manufacturing Sector that was established in this period also persisted after the Second World War until the decade of the 1990s and some features are still with us. For example, looking at the series for PMV and for Blankets in Figures 2 and 4, we see that the high rates established in the period leading up to and during the Great Depression persisted, with some variation, until the mid-1980s.

For the period of the Second World War, the statistics of average tariffs are not comparable with those for the earlier and later non-War years. The Second World War disturbed commodity trade flows and revenue collections to a much greater extent than the First World War. The sources of imports changed substantially as the UK was unable to continue to supply many of the goods which it had previously supplied. Private imports were restricted by import licensing and exchange controls. However, the value 
of trade increased during 1941-42 and subsequent years as imports on government account of war supplies surged. The US became a much more important source, especially of war supplies. These imports of war supplies were financed by Lend Lease and Mutual Aid agreements between the Australian and US governments. With respect to customs duties, special War duties were levied on all imports except for exempt goods at the rate of 10 per cent of the amount of duty including Primage (but these War duties are not included in the statistics of customs duty collected). Offsetting this, imports of war supplies were duty free. This explains the sharp fall in the average tariff on all clearances. After the Second World War trade returned rapidly to a normal pattern. ${ }^{4}$

The major break in 1947 in the series is associated with the change in the method of valuation of imports. After the adjustment for the change in the method of valuation, there is still a fall in the ratio in 1947-48 according to both series, indeed the largest fall recorded in the 100 years. This is surprising as one expects the series to be unchanged between 1946-47 and 1947-48, apart from any change due to changes in statutory tariff rates or in the composition of imports. There were no changes in statutory rates in this year apart from those required to effect the change in the method of valuation. In 194748 , there was a 27 per cent increase in duty collected but the value of dutiable imports surged by 76 per cent, much larger than the 25 per cent change due to the change in the method of valuation.

There was a sharp spike in the average duty on dutiable clearances in 1952-53. This movement is unusual in that it was not due to an increase in tariff rates. Rather there was a sharp rise in imports of dutiable goods in 1951-52 relative to free imports at the peak of the Korean War boom, followed by a sharp fall in these imports in the following year.

There was a fall in the average tariff in 1973-74, especially for the series relating to all clearances. This was due to the 25 per cent across-the-board cut in all tariff rates in July 1973. This was the first systematic cut in tariff rates ever done in Australia, though the

\footnotetext{
${ }^{4}$ While this is generally true, Lloyd, Discrimination Against Imports, showed that many of the tariff rates levied on tariff items matching exciseable items had a substantial protection margin.
} 
policy motive was to reduce the rate of inflation not to improve the efficiency of production. It was controversial at the time as many blamed it for the subsequent rise in unemployment. A number of economists believed that this experience would prevent further reductions in protection. Viewed as an observation in the 100 year series of average rates in Figure 8, it shows, remarkably, as a minor blip in the series. One contributing factor is that the Government, following the recommendation of the Committee which reviewed the alternatives (Rattigan Committee Report, 1973), exempted tariff items matching exciseable items as it was considered these duties were levied for revenue purposes not for protection ${ }^{5}$. Thus the tariff cut was, when expressed across all import items, roughly a 20 per cent tariff cut. Another factor was that the automobile industry and some other protected industries succeeded in having the tariff rates on competitive imports restored to pre-cut levels within 12 months: for example, the MFN rate on assembled passenger motor vehicles, reduced from 45 per cent in 1972-73 to $33.75(=45 x 0.75)$ per in 1973-74 cent, was restored to 45 per cent in December 1973 (see Figure 1). Other tariff rates were increased in a piecemeal fashion in the following years. Average tariff rates again rose and surpassed those prevailing before the cut by 1978-79.

Looking at the series as a whole now, perhaps the most important feature is the peak or peaks. These long term series have two peaks. The first was during the 1930s. The average duty on dutiable imports was over 50 per cent in all years except one in this decade and peaked in 1931-32; in this year the rate is 72.0 per cent for the series before the adjustment for the change in the method of valuation and 63.4 per cent for the final adjusted series. The average duty on all clearances was over 30 per cent in all years except 1937-38 and peaked in 1931-32, the same year as in the other series; in this year the rate is 42.2 per cent for the series before the adjustment for the change in the method of valuation and 37.1 per cent for the final adjusted series.

The second peak was in the late 1970s and early1980s. While the absolute levels of the two measures of average tariffs are much lower in this peak period than they had been in the 1930s, there is still a clear peak in both series.

This peak contrasts with the estimates of the average nominal rate of assistance to the Manufacturing Sector made by the Tariff Board and its successors. (See Lloyd, 2006, pp. 
302-304). These show an almost uninterrupted decline since the series begin in 1968-69. The Tariff Board/IAC/IC/PC series includes the effects of non-tariff measures as well as tariffs and uses fixed production weights in place of current period import weights. This may explain some of the difference. The slightly different behaviour of these alternative series of average tariffs reflects the ambiguity of assistance policy during the late Seventies and early eighties, with some rates being increased and some increased. Note that the preferred series for Blankets peaks in 1982-83 whereas that for Passenger Motor Vehicles has a long peak sustained from 1978-79 to1987-88. (See Tables 1 and 2.)

The downward trend in average tariffs since that time has been due to the continual reforms of Australian tariffs. Productivity Commission (2003) gives a brief history of the main events and further detail is given conveniently in the Productivity Commission's annual Trade and Assistance Review. There has been an uninterrupted decline in both series since 1988-89. This was due principally to the strategy of phased reductions in tariff rates that was introduced in the 1988 Economic Statement by the Hawke Government. This strategy had a much greater effect than all other piecemeal reforms, including the 1973 across-the-board tariff cut.

Most of the changes after the second peak are due to the lowering of the MFN rates under the Tariff Review and the annual phased reductions in tariffs. Phasing of tariff reductions across a large number of items was an important innovation that became the dominant factor in tariff reform. These were supplemented by the periodic reviews of the substantive tariff rates in the CTF and Automobile and other industries.

However, several factors other than the cuts in MFN rates contributed to the decline in average tariffs after the mid-1980s. One significant factor was the conversion of non-ad valorem rates to ad valorem rates. A second significant factor was the elimination of protection for goods which are subject to excise taxation when produced in Australia. A third minor factor was the fall in contingent protection; the fall and then the ending of temporary assistance in 1984 and later the fall in the incidence of anti-dumping and countervailing duties collected. Another substantial factor was the introduction of preferential rates below the MFN rates. The first major contribution was the Closer Economic Relations Agreement with New Zealand in 1983 and then in the 1990s, at the end of my series, the Agreements with Singapore, Thailand and the US. 
The two series of average tariffs discussed in this Section and particularly the series of the average tariff on dutiable imports are, in my opinion, valuable series. They give us reliable indicators of change in average protection and the events and factors that have caused these changes.

This Section makes some general comments on applications of the series of average tariffs.

One application of the observed series is a political economy explanation of the main trends and turning points. There have been a number of attempts, using political economy models of democratic processes, to explain empirically the inter-industry variation in nominal or effective rates of assistance to manufacturers or primary producers in Australia at particular times; for example, Anderson (1978, 1980) and Quiggin (1989). The long term series presented in this paper shed some light on these political economy explanations.

It is evident from the series of average tariffs and from the series for selected individual commodities that the general pattern of inter-industry variation among importables was largely fixed by the mid-Thirties. Hysteresis rules.

A second possible application of long term series of rates of protection in Australia is to combine this information with other series in explaining the long term behaviour of the Australian macro-economy, particularly perhaps the rate of growth. As a result of celebrations of the centenary of the Federation of Australian States in 2001, some long term series of other aspects of the Australian economy have been put together. For example, the Treasury (2001) has constructed a 100 year series of unemployment rates, and the Department of Immigration, Multicultural and Indigenous Affairs (2001) has constructed 100 year series of immigration flows into Australia.

A third possible application is a comparison of the Australian series with series for other countries. The US International Trade Commission has constructed historical time series of average tariffs in the US. These go back to the $19^{\text {th }}$ century. 
Surprisingly, the same methods have been used in both countries so that the two national series are comparable. Both the ITC and myself have constructed two principal series of the average tariff, one for all imports and one only for imports that are dutiable. Of these I have chosen here the index that relates to dutiable imports only. Both the ITC and myself have constructed Paasche indices, using current import values as weights. And both the US and Australia use an fob valuation for the determination of duties. My series used here is the series adjusted for the change in the 1947 method of valuation.

Figure 11 graphs the US and the Australian series of the average tariff on dutiable imports only. The US series tends to be smoother, with less year-to-year variations and smaller reversals in direction. This is because the US tariff rates have been changed by legislation much less frequently than the Australian rates which change significantly in almost every year for some commodity groups. Apart from the annual variations, the two series show an amazingly similar path and, in particular, the main turning points occur in the same year or years in several instances.

This result is surprising. In both the US and in Australia commentators have identified key national legislation that has changed the levels of tariff rates. In the US, the ITC (2006) divides the tariff history into periods associated with the major tariff Acts; the McKinley Law, the Wilson Law, the Dingley Law, the Payne-Aldrich law, etc. In Australia, we refer to the Lyne Tariff, the Greene tariff, the Pratten Tariff, the Scullin Tariff, the 1973 Tariff Cut, etc. That is, the explanations of the turning points in both countries have been presented in terms of domestic political events and changes in governments. However, when we consider the two series, it is apparent that they have moved together most of the time. The notable exception is the second peak in the Australian series in the late 1970s and early 1980s. By contrast in the US tariff rates declined through this period.

Clearly there is something much larger than domestic policies at work. This comovement can be attributed to common global influences. For example, both the US and the Australian tariff rates peaked in 1930 with the passage of the Smoot-Hawley Law in the US and the Scullin Tariff in Australia. Both of these Acts were passed in the early years of the Great Depression when countries around the world adopted 
similar beggar-thy-neighbour policies. On the brighter side, US and Australian rates fell in 1947. The US change is attributed to the first GATT Round of tariff negotiations whereas that in Australia occurred at the time of a raft of changes centred on the change in the method of valuing imports (itself a result of Australia becoming a founding members of the GATT). Since that time, the series has moved steadily downward in the US, chiefly as a result of successive GATT rounds, but the Australian series did not moved steadily downward until the mid-1980s. Australia did not participate actively in the GATT Rounds until the Uruguay Round but its domestic policy was influenced by the global debate about the benefits of tariff reform. Nations are not islands when it comes to policy formation. There is a process of transfer across borders of policy ideas and views that has as yet received little attention but it is clearly important.

These and other applications deserve attention but the starting point is the examination of long run series such as those presented in this paper. 


\section{REFERENCES}

Anderson, K. (1980) The Political Market for Government Assistance to Australian Manufacturing Industries. Economic Record, 56: 132-44.

Anderson, K., P. J. Lloyd and D. MacLaren (2008) Australia and New Zealand. In K. Anderson (ed.), Distortions to Agricultural Incentives: A Global Perspective, (Washington, D. C., Palgrave Macmillan and World Bank), forthcoming.

Athukarola, P. and Chand, S. (2007), Tariff-Growth Nexus in the Australian Economy, 1870-2002: Is There a Paradox?. Working Paper in Trade and Development No. 2007/08 (Canberra, Research School of Pacific and Asian Studies, the Australian National University).

Brigden, J. B., Copland, D. B., Dyason, E. C., Giblin, L. F.,Wickens, C. H. (the Brigden Committee) (1929), The Australian Tariff: An Economic Enquiry (Melbourne, University of Melbourne Press).

Carmody, A. T. (1952) The Level of the Australian Tariff: A Study in Method. Yorkshire Bulletin of Economic and Social Research, 4: 51-65.

Commonwealth of Australia (1906), Report of the Royal Commission on the Commonwealth Tariff, (Canberra, Commonwealth of Australia).

Corden, W. M. (1963) The Tariff. In A. Hunter (ed.), The Economics of Australian Industry (Melbourne, Melbourne University Press).

Crawford, J. G. (1939) Tariff Level Indices, Economic Record, 11, 213-221.

Committee of Enquiry (The Vernon Committee) (1965), Report of the Committee of Enquiry (Melbourne, Wilke and Co).

Department of Immigration, Multicultural and Indigenous Affairs (2001), Immigration Federation to Century End (Canberra, Department of Immigration, Multicultural and Indigenous Affairs).

House of Representatives (1947), Hansard, pp. 1499-1500, 2143.

Irwin, D. A. (2006) The Impact of Federation on Australia's Trade Flows. Economic Record, 82: 315-324.

League of Nations (1927), Tariff Level Indices (Geneva, League of Nations).

Lloyd, P. J. (1975) Discrimination Against Imports in Australian Commodity Taxes. Journal of World Trade Law, 9: 89-101. 
Lloyd, P. J. (2006) Fifty Years of Trade Policy Reform in Australia. Economic Papers, 25: 301-313.

Lloyd, P. J. and D. MacLaren (2007) The Partial Equilibrium TRI. University of Melbourne.

Nicholson, D. F. (1955), Australia's Trade Relations: An Outline of Australia's Overseas Trading Arrangements (Sydney, F. W. Cheshire).

Pincus, J. (1995) Evolution and Political Economy of Australian Trade Policies. In R. Pomfret (ed.), Australia's Trade Policies (Melbourne, Oxford University Press).

Productivity Commission (2003) From Industry Assistance to Productivity: 30 Years of 'the Commission' (Melbourne, Productivity Commission).

Rattigan Committee Report (1973) Report on Possible Ways of Increasing Imports (Canberra, Australian Government Publishing Service).

Quiggin, J. (1989) The Role and Consequences of Special Interest Groups and Political Factors. In B. Chapman (ed.), Australian Economic Growth (South Melbourne, Macmillan).

The Treasury (2001) Australia’s Century since Federation at a Glance. In The Treasury, Economic Round-up Centenary Edition (Canberra, Treasury), pp. 53-63.

Vamplew, W. (ed.) (1987) Australian Historical Statistics (Sydney, Fairfax, Syme and Weldon Associates). 
Figure 1. Passenger Motor Vehicles Statutory Tariff Rates

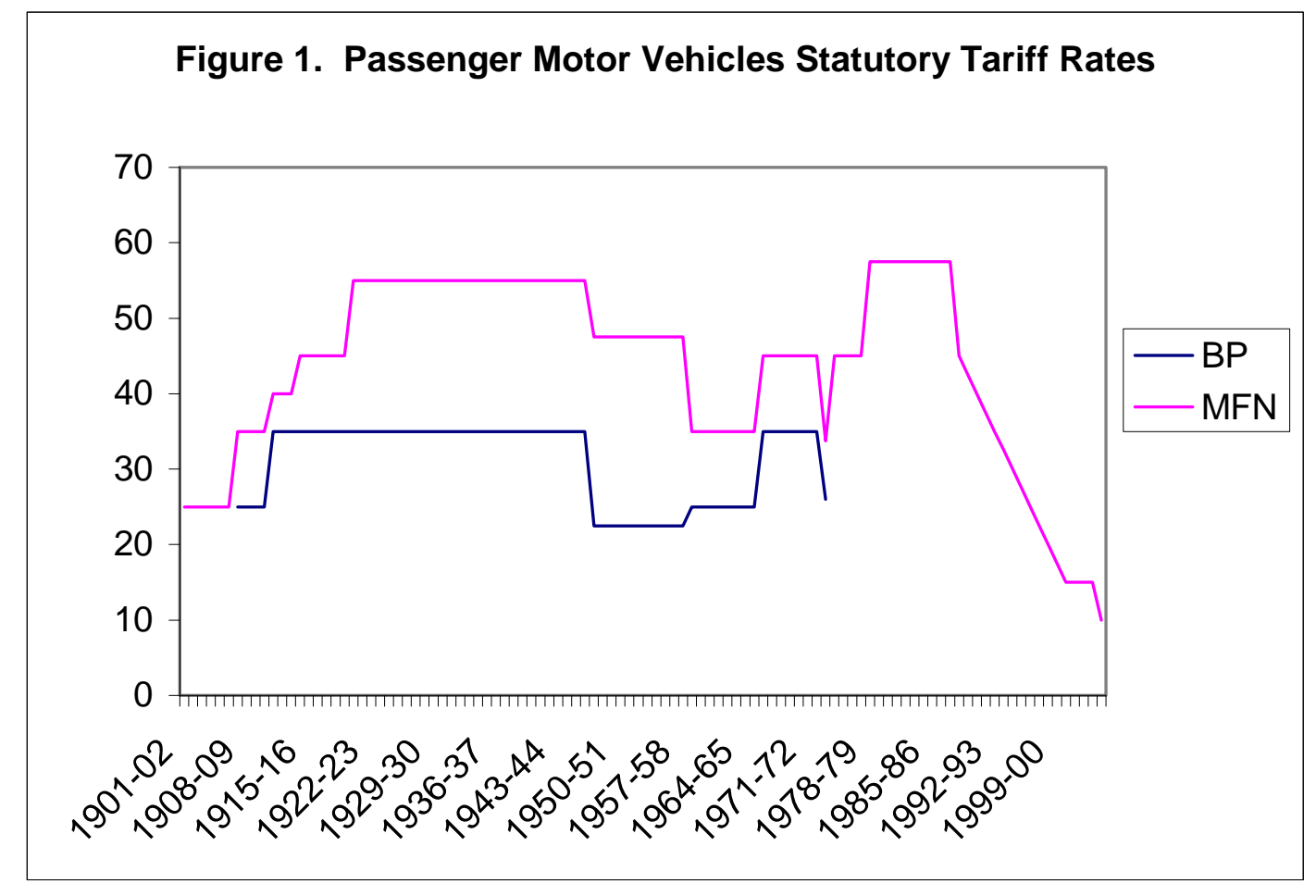


Figure 2. PMV - Average Tariff with (solid line) and without (broken line) adjustment for method of valuation

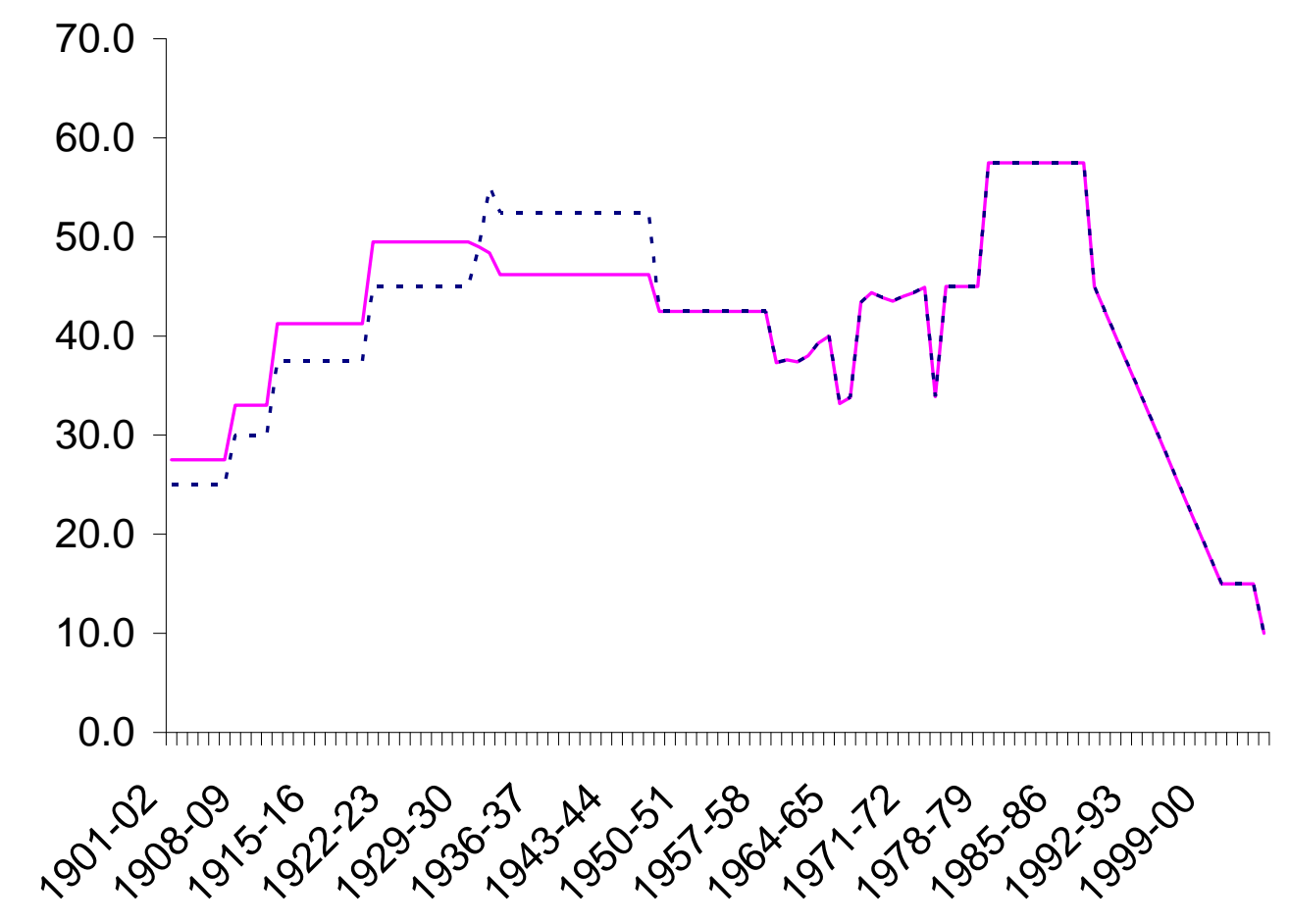




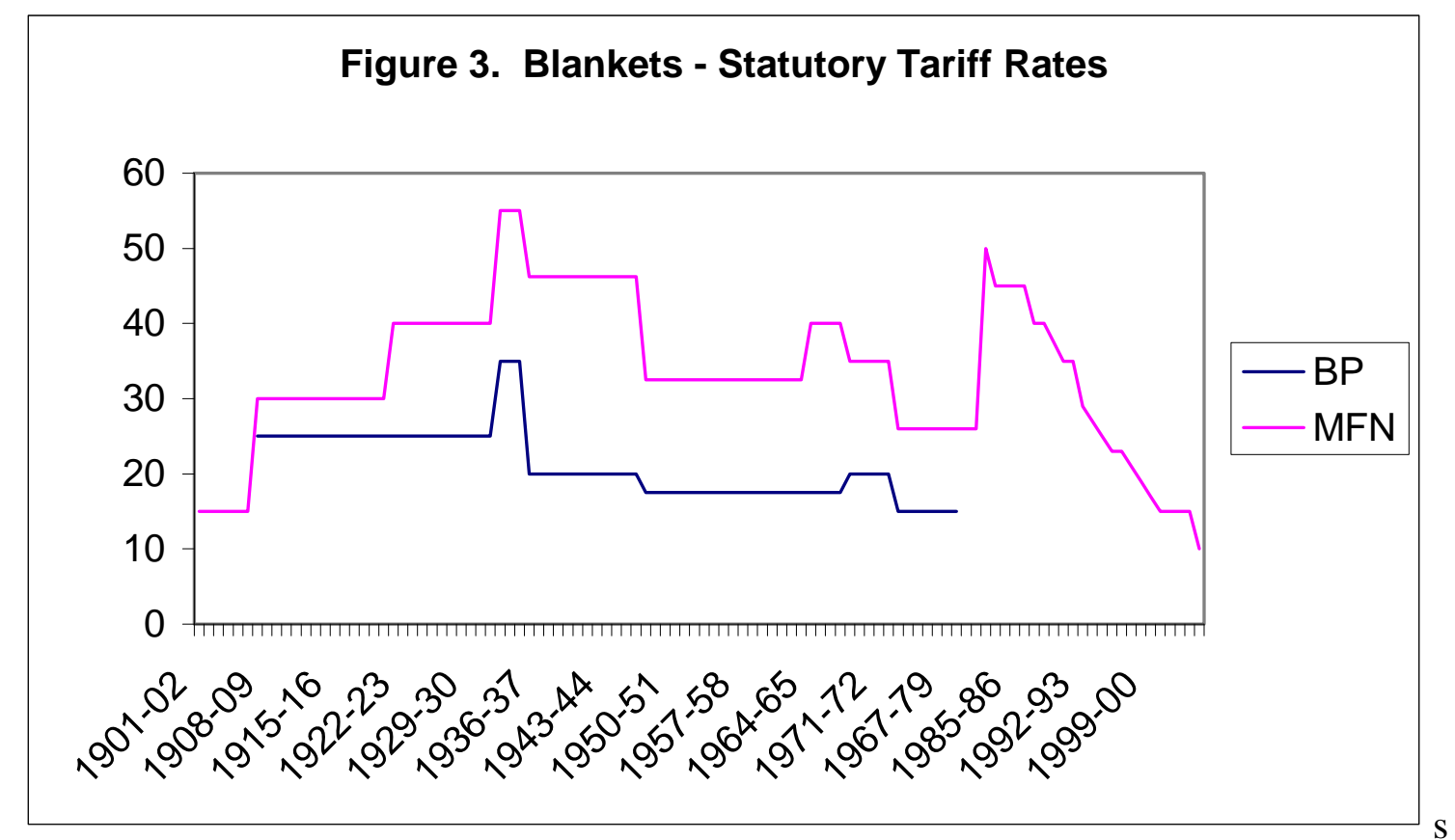


Figure 4. Blankets - Tariff Rates, with (solid line) and without (broken line) adjustment for method of valuation

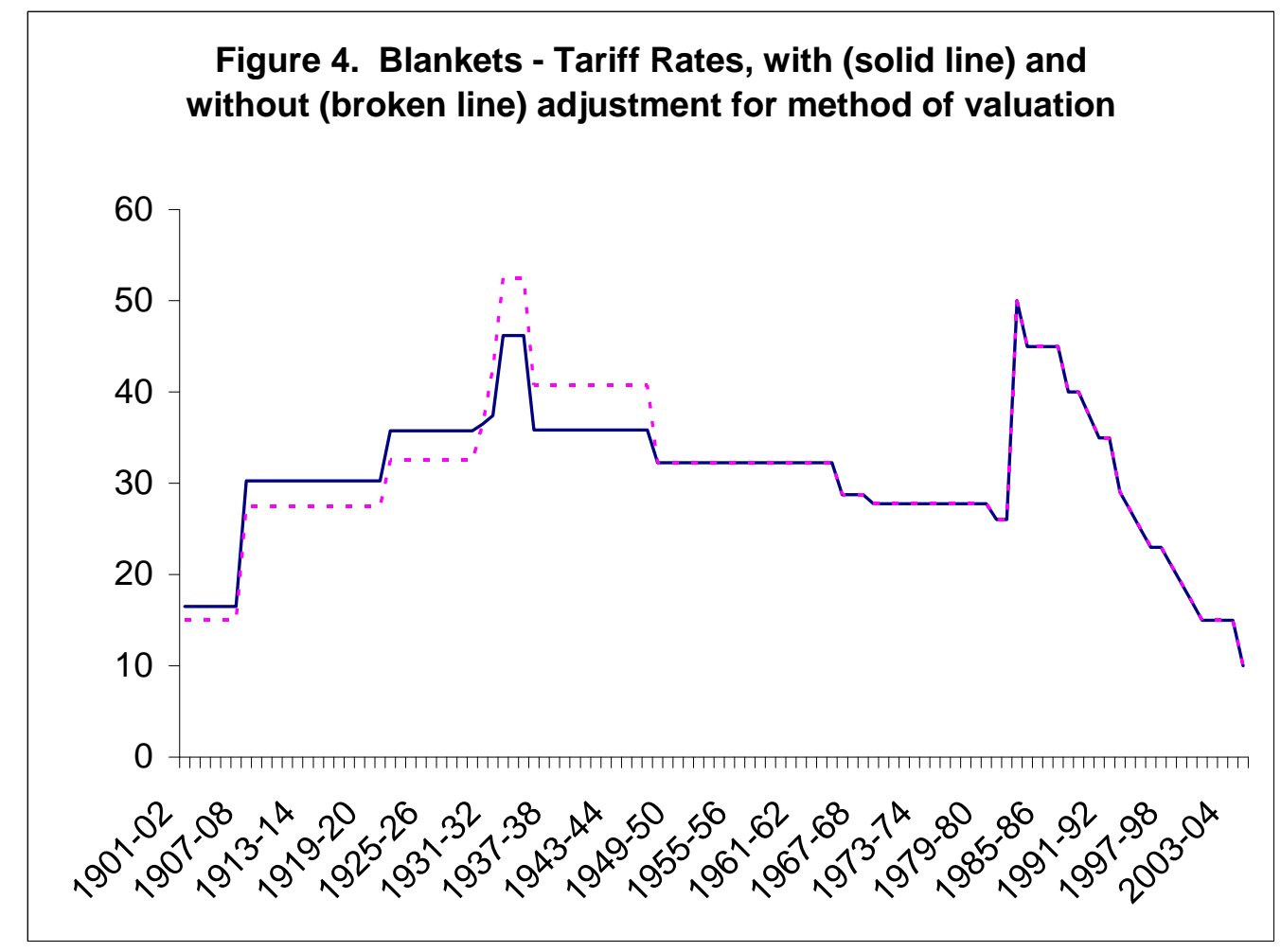


Figure 5. Beer - Average Tariff Rate

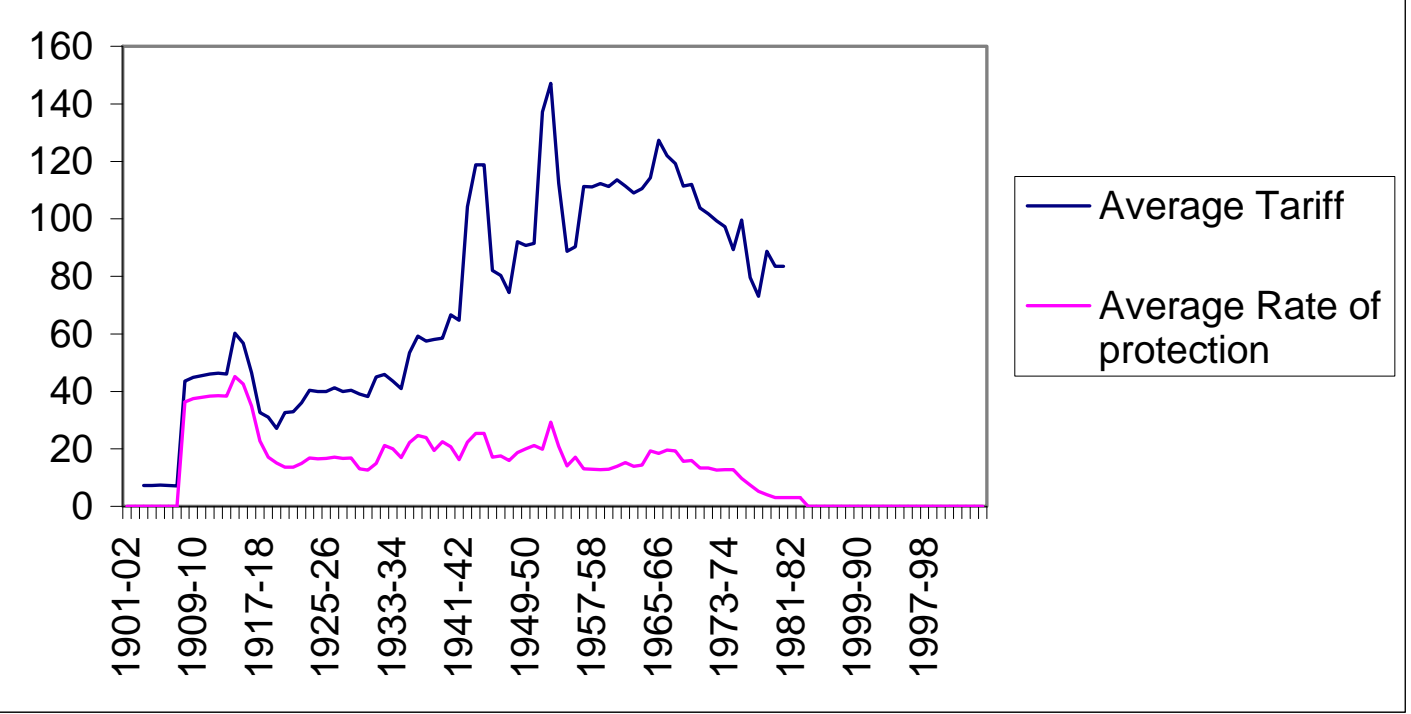


Figure 6. Beer - Tariff Rates, with (solid line) and without (broken line) adjustment for method of valuation

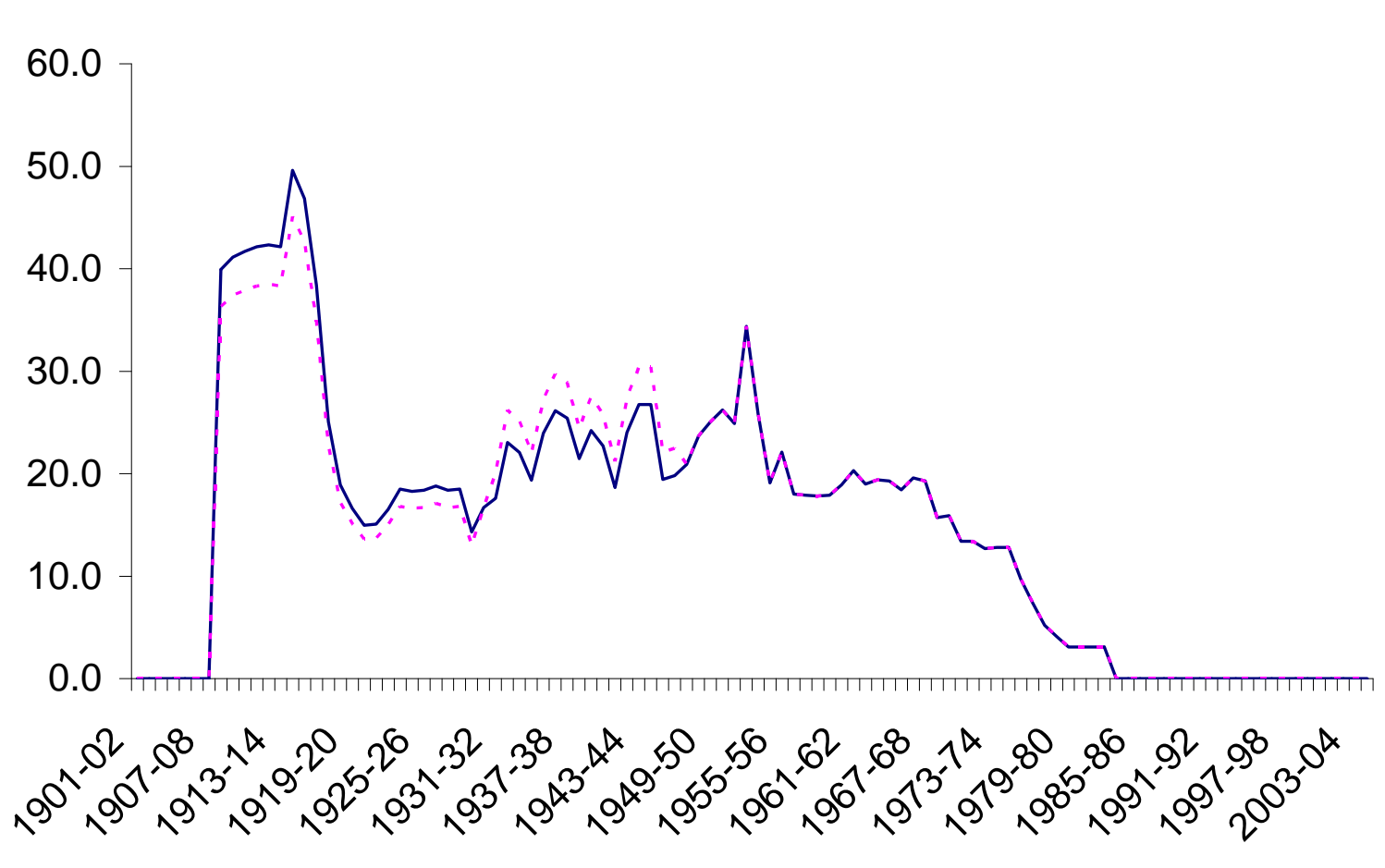




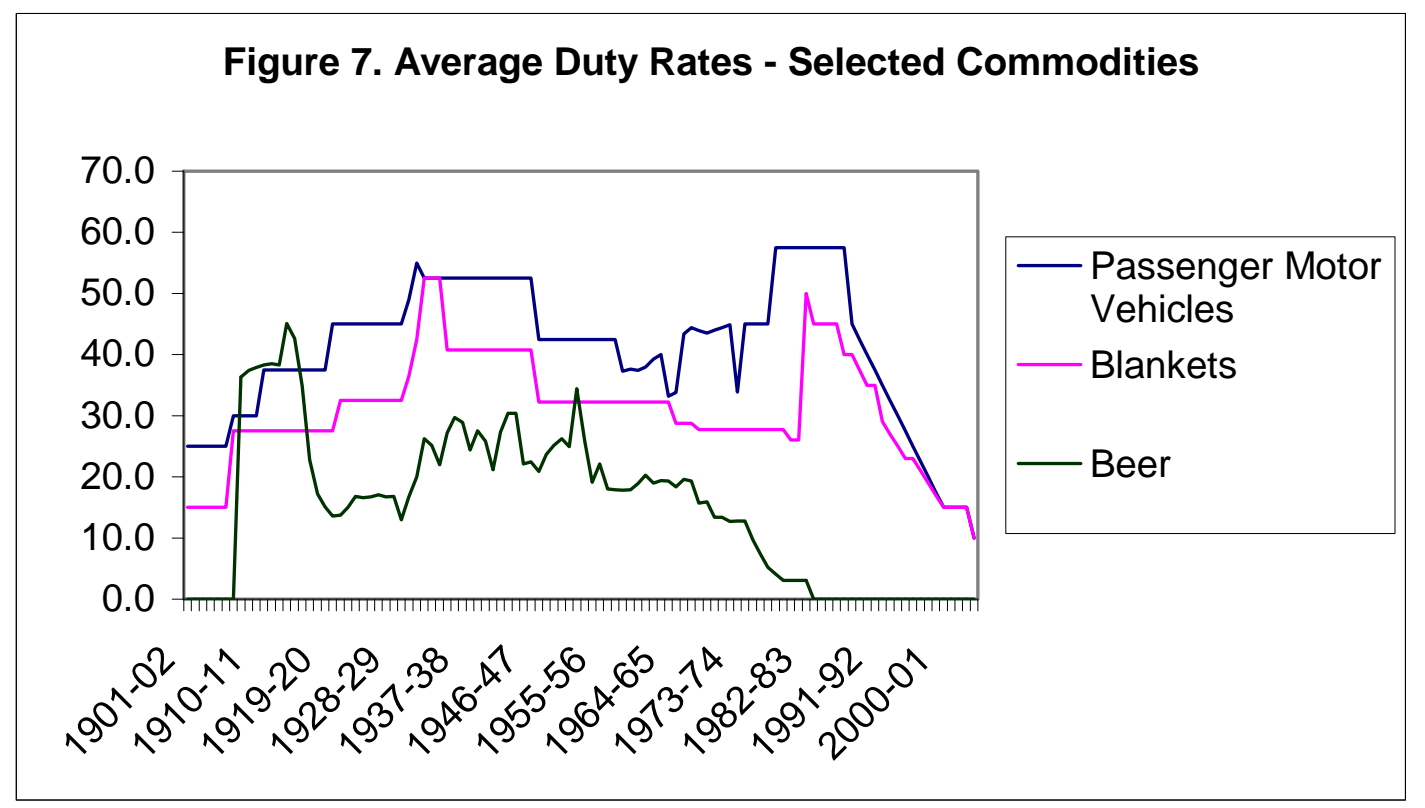


Figure 8. Estimates of the average duty on all imports, Australia, 1988-89 to 2004-05

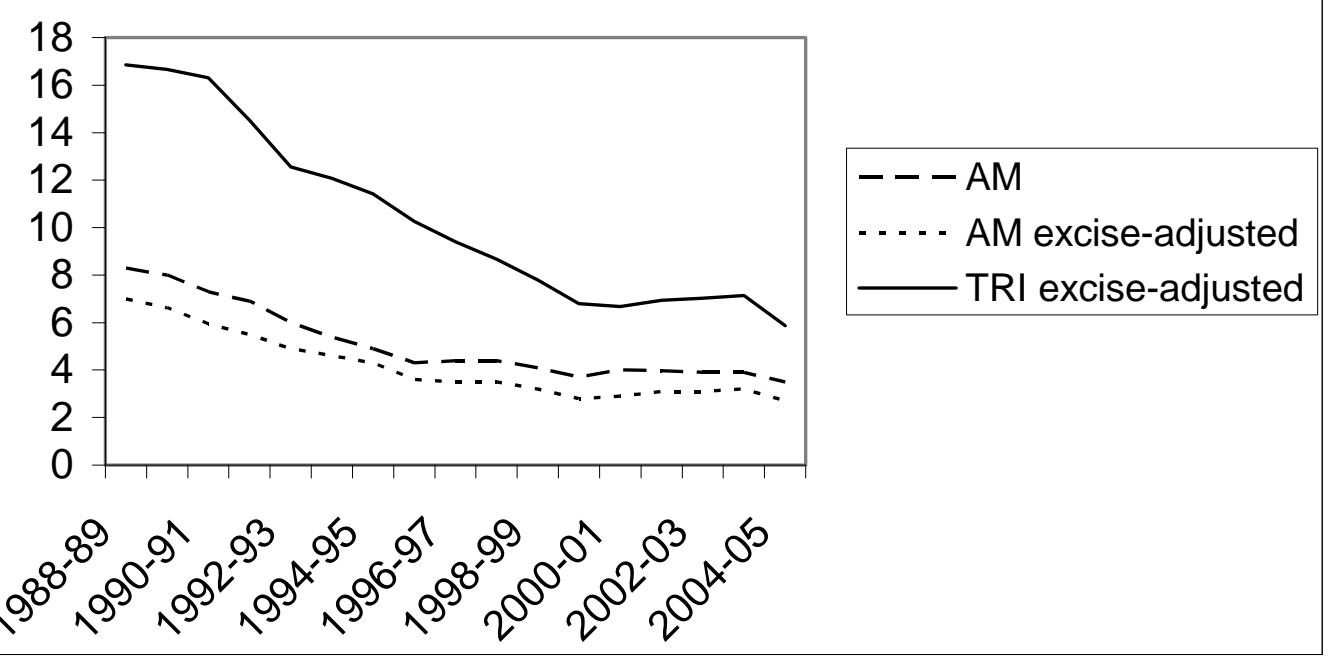


Figure 9. Average Duties, 1903-04 to 2004-05




Figure 10. Average Duties, adjusted for method of valuation, 1903-04 to 2004-05

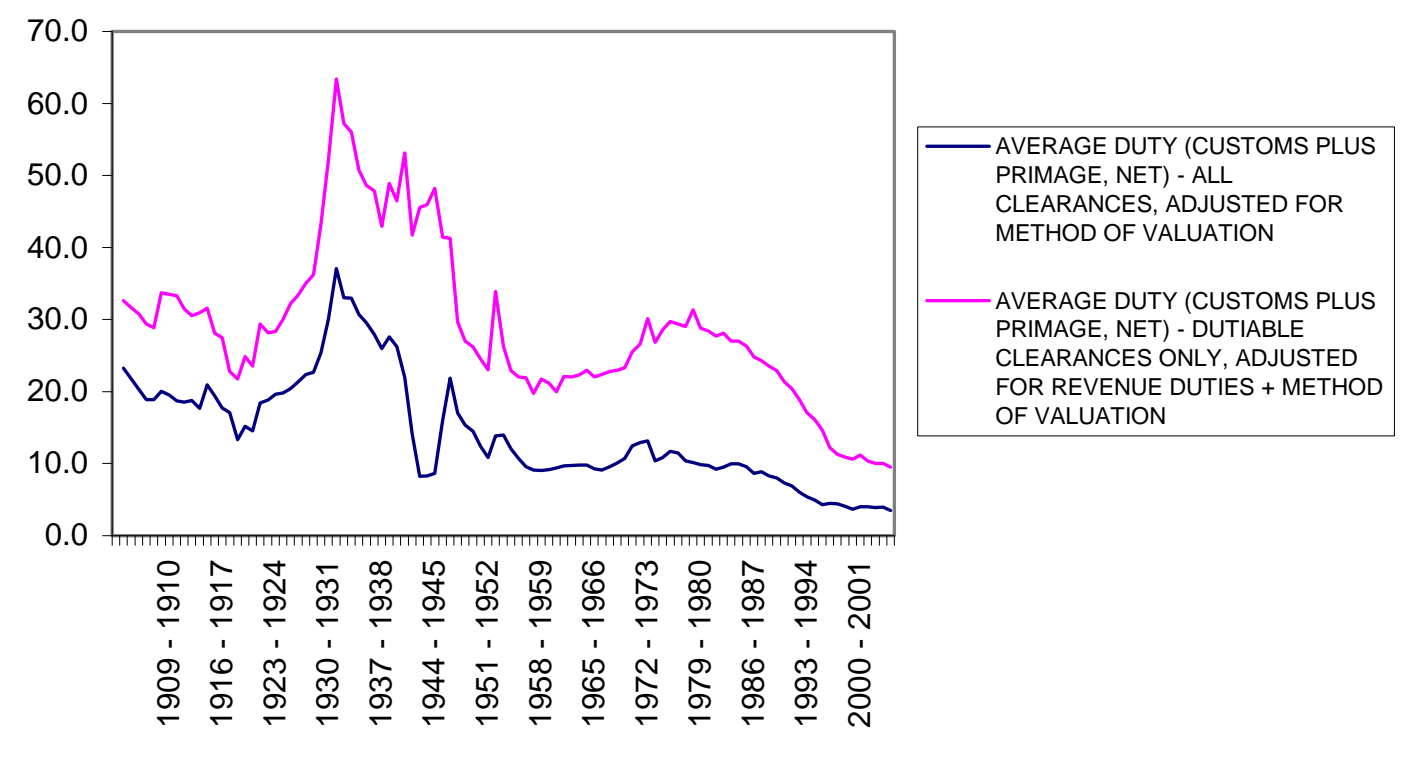


Figure 11. Australian (solid line) and US (broken line) Tariff Rates

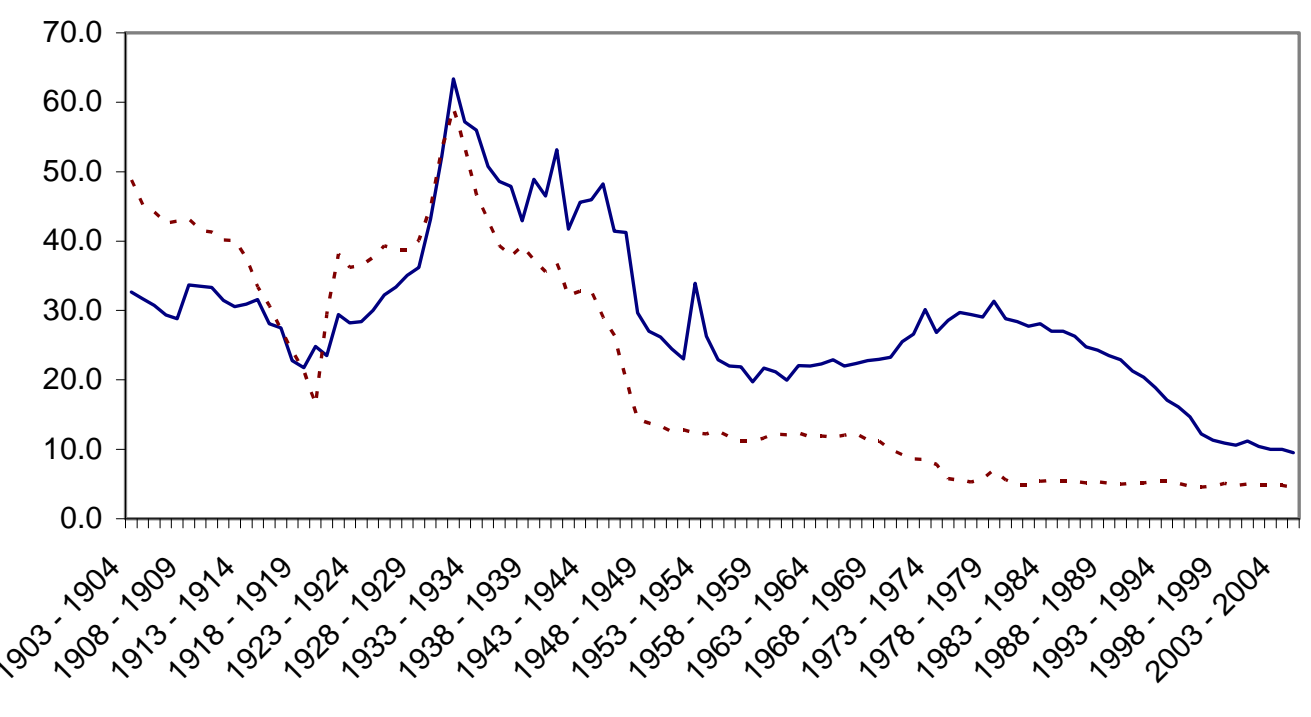




\section{Appendix 1. Notes on Sources of Data for Tables 1, 2 and 3}

For all three product groups, the ad valorem or specific tariff rates reported in each year are the statutory rates. All rates are taken from Commonwealth Acts; Customs Tariff Acts, Customs Tariff Amendment Acts, Tariff Validation Acts, Customs Tariff (Primage Duties) Act and other Acts and Tariff Proposals that legislated a change in duty for the product group. Careful note has been taken of the time the new rates became effective. In years when the rate was changed during the financial year, the rate reported is the rate which applied for the longer period, which must be longer then six months.

For the two product groups of Passenger Motor Vehicles and Blankets, Tables 1 and 2 report two rates. One column of each table shows the BP rate. The other column shows, when the Customs Tariff had three columns, the Intermediate (MFN) rate and when there are only two columns, the General (MFN) rate. These rates are, with the exceptions of imports from Japan before it was granted MFN treatment in 1965 and a few other minor cases, the minimum and the maximum rates for the item in the year concerned. For Beer, the MFN and BP rates are not reported as the focus in this group is on the ad valorem equivalents of the customs and excise duties and the nominal rate of protection.

The tariff rates are the substantive rates that apply to "Normal” imports of goods within the tariff item on which duty is paid. Government imports and private imports on which a concessional rate is paid because of a by-law or concession (such as imports sourced from Developing countries) enter at lower rates of duty, frequently a zero rate.

Of the preferential rates that were applied to Normal imports of Passenger Motor Vehicles from various sources over different intervals, only the British Preferential rates are used. The same procedure is used for Blankets.

For each of these three commodities, Primage duties applied for a period. There was a statutory (ad valorem) Primage duty rates for imports from all sources which were not exempt (New Zealand and some of the Pacific Islands) and not preferred. There was a lower rate on certain imports which, for the purpose of assessment of tariff duties, were imported at BP Preferential rates. British Preferential Primage rates applied from 1934. Thus, like tariffs, there were two non-zero rates on each item subject to Primage duties, 
except for the first two years. In periods when British Preferential Primage rates applied to the commodities considered here, a simple average of the non-Preferential and the British Preferential Primage rates has been used each year.

It is also necessary to adjust these commodity group tariff rates for the change in the method of valuing imports introduced in 1947. This adjustment is made for the years 1902-03 to 1946-47. The method used to make these adjustments is outlined separately in Appendix 2.

\section{Table 1. Passenger Motor Vehicles}

The tariff item is the item each year relating to new motor vehicles used for private passenger transport. It excludes buses and other vehicles used for public transport of passengers, and motor cycles. In the period after the Second World War when the range of motor vehicles greatly increased, it includes station wagons and vehicles such as ambulances but excludes Light Commercial Vehicles and four-wheel drive vehicles (both of which have been subject to lower rates of duty). In all years the item relates to the fully-assembled final product.

Primage duties, which applied to this group over more than 30 years from 1930-31 to 1965-66, have been included. The rate of Primage duty was 10 per cent, except for the year it was introduced, 1930-31, when it was 4 per cent. However, from 1932 imports admitted from Great Britain paid a lower preferential Primage duty of only 5 per cent when the Primage rate on imports from General sources was 10 per cent. For the period 1931-32 to 1964-65 I have used the mid-point of the General and the BP Primage rate (7.5 per cent) in order to be consistent with the treatment of tariff rates over this period. In the Customs Tariff 1966 Primage duties were abolished on this product group. Hence, for the years from 1934 to 1965 it was a minor additional source of protection for the domestic industry.

\section{Table 2. Blankets}


The tariff item is the item relating to a closely related group of products described as blankets, blanketing and rugs or similar terms, here called "Blankets". For all of the period blankets or rugs made of rubber have been excluded.

From 1935 to 1982 this group was split into blankets made from wool and those made from cotton and sometimes other materials such as synthetics which carried different rates. During this period cotton blankets were subject to lower rates of duty than woollen blankets; for example, when the item was split in the Customs Tariff 1936, the new rate of duty on woollen blankets imported from General sources was 46 1/4 per cent whereas that on cotton blankets from General sources was only 25 per cent, while the corresponding British Preferential rates were 25 per cent and 5 per cent respectively. In 1982 the different sub-items for blankets made from wool and those from cotton continued but the rates of duty were again the same. When the rates of duty for blankets made from different materials were themselves different the rate for blankets made from wool has been chosen. Thus, the series is one for tariffs levied on blankets made from wool, but for most of the period the same rates applied to blankets made from other materials. The tariff was designed to give protection to Australian manufacturers of products made from Australian wool.

\section{Table 3. Beer}

The tariff item is the item for beers with an alcohol strength greater than the stipulated minimum. For the first 70 years the minimum was 2 per cent proof spirit but in 1972 the definition of the alcohol content was changed to the content measured by volume and the minimum was reset at 1.15 per cent by volume of alcohol.

In 1911 the item was split into beer imported in bottles and in bulk; the tariff rates at the time were 1s 6d and 1s per gallon respectively. Later and until 1965 the split was defined in terms of beer imported in containers not exceeding/exceeding one gallon. During the period of this split, the rate for bottled beer or beer in small containers has been used as this accounted for most imports.

For this product group, we also need to consider the excise item as Australian-produced beer is an exciseable item. This excise item has been defined in the same way as in the tariff item throughout the 100 year period. 
Prior to 1984, there was a single flat excise rate and a single flat customs rate for Beer. From August 1984 to August 1988, there was a split in both the excise taxation and the customs taxation on the basis of the alcohol strength, into medium alcohol beers (defined as those for which the alcohol content was between 1.15 and 3.8 per cent) and full strength beers (defined as those for which the alcohol strength was greater than 3.8 per cent).

From August 1988 both imported and locally-produced beer has been taxed on the basis of its alcohol content rather than the volume. At this time, a single rate was restored in both the excise tax and the customs duty for beers with an alcohol content exceeding 1.15 per cent by volume. In July 2000 the present distinction between six categories of beer, each with its own rate, was introduced in the excise tax and the customs tariff. The rates for beers with an alcohol content exceeding 1.15 per cent by volume distinguished between low, medium and full strength beers in terms of their alcohol content and, for each of these strengths, there is one rate for draught beer (defined as beer in individual containers exceeding 48 litres) and non-draught or packaged beer (cans and bottles).

I have expressed the specific duties of both periods in a common unit. The basis chosen is the convention used until 1988 of expressing rates in terms of dollars per litre of fluid as the quantities of beer produced locally and imported are still measured in fluid litres. To do this, the annual statutory tariff and excise rates in years before the introduction of decimal currency in 1965 and before metrication of volume measures in 1973 and before the calculation of duties based on alcohol content in all have to be converted to the present expression of duty rates in terms of dollars per litre of fluid. For example, at the time excise and customs tariffs on beer were introduced in 1901, both the excise rate the customs tariff rate were $3 \mathrm{~d}$ per gallon. This is equivalent to $\$ 0.025$ per gallon or to \$0.0055 per litre. The second conversion has been done at the rate of 0.21996 Imperial gallons per litre. These series are in columns (2) and (3) of Table 3.

Two sources were used to calculate the average specific customs duty levied and the unit values of imports. For the period up to the end of World War II, the data is extracted from the annual volumes of ABS Overseas Trade Bulletins (available from the ABS Historical microfiche series for ABS Catalogue No 5409.0). The British Preferential rate 
and the unit value of imports from the UK alone were used for this period as almost all imports in all years were sourced from the UK. For the period since World War II and up to the introduction of electronic series, the data is extracted from the annual volumes of ABS Imports cleared for Home Consumption (available from the ABS Historical microfiche series for ABS Catalogue No 5412.0). For this period, import source became more diversified and, consequently, the average duty is the average over all sources and the unit value is correspondingly the unit value for imports from all sources.

Next, the difference between these average statistics is taken.

Then, the difference between the average tariff and the average excise duties levied on beer each year must then be expressed in terms of an ad valorem equivalent rate. This done by dividing the difference in rates by the average unit value of imports in each year and expressing this ratio as a percentage. This method of calculating the ad valorem equivalent rate implies that the price before taxation of locally produced beer is the same as the price of imported beer. An alternative method in principle is to divide the (average) excise duty by the unit price of locally-produced beer and the (average) customs duty by the unit value of imports, expressing both in percentage terms, and then to take the difference of these two rates. However, there are no statistics in Australia of the unit price of locally produced beer when it is cleared from the breweries licensed for beer production and excise duty is collected.

For one of the years during the Second World War, 1944-45, there were zero imports. To maintain the continuity of the series, I have set the rates for this year equal to that of the preceding year. There are two years, between the end of ABS microfiche records of imports cleared for home consumption in 1980-81 and the elimination of the differential between the specific customs and excise rates on beer, when it is not possible to estimate the rate of protection exactly. These are the years 1981-82 and 1982-83. In both of these years the differential between the specific customs and excise rates on beer was maintained at the level holding in 1980-81. I have used the ad valorem equivalent for 1980-81 for the two subsequent years as an estimate of the protection in these two years. As unit import values may have rose in these two years, this may be a slight overestimate. 
Finally, the ad valorem Primage duty must be added for the period 1930-31 to 1963-64. In 1930-31 the Primage rate was 4 per cent, and from 1931-32 to 1963-4 the BP Primage rate was 5 per cent and the general rate was 10 per cent. The BP rate has been used throughout this period as UK imports still predominated.

Since August 1983 all imported beer has been taxed at exactly the same rate or rates as locally-produced beer or beers, hence, there is no need to specify the rate or rates that apply to locally-produced and imported beers in this period. 


\section{Appendix 2. Valuation of Imports}

The amount of duty collected on an imported good subject to an ad valorem duty is the product of the percentage duty rate and the value for duty. For a given shipment of goods and a given tariff rate, a change in the valuation alone changes the duty collected and, therefore, the protection of the domestic industry.

Before 1947, a shipment of goods imported into Australia was valued at $£$ Stg fob +10 per cent $=£$ Stg fob(1.1). After 1947, the value for duty became $£$ A fob. To give a consistent series over the 100 years, I have chosen to express all tariff rates as the percentage rates that would apply under the later convention of valuing imports $£ A$ fob. To achieve this, all ad valorem rates and average rates for years before 1947 must be adjusted; this applies to both customs duties and Primage duties. For these years, the adjusted ad valorem rate is that rate which, together with the current convention of defining value for duty, would yield the same revenue, and therefore give the same protection, as the actual rate that applied with the old convention.

\section{(i) The adjustment for individual commodities}

To make the adjustment for an individual commodity, commodity i, which is imported at some time before 1947 and subject to an ad valorem tariff rate $\left(t_{i}\right)$, we use the adjusted ad valorem rate

$$
\mathrm{t}_{\mathrm{i}, \mathrm{adj}}=\mathrm{t}_{\mathrm{i}, \mathrm{pre}-1947} \times\left[\mathrm{V}_{\text {pre-1947 }} / \mathrm{V}_{\text {post-1947 }}\right]
$$

$t_{i, \text { pre-1947 }}$ is the rate that applied with the old convention of valuation. $V_{\text {pre-1947 }}$ and $V_{\text {post- }}$ 1947 are the value for duty under the old and the new conventions respectively. In effect, this takes the duty collected under the old convention and divides it by value for duty under the new convention. This is equivalent to

$$
\mathrm{t}_{\mathrm{i}, \text { adj }}=\mathrm{t}_{\mathrm{i}} \mathrm{x}[£ \operatorname{Stg}(1.1) / £ \mathrm{~A}]
$$

The adjustment factor is, therefore, [£Stg(1.1)/£A]. This factor will generally vary from year to year.

The same adjustment factor is applied to an ad valorem equivalent rate as the denominator is the value of the imports. 
For the period 1931-32 to 1946-47 when the Australian pound devalued vis-à-vis pound sterling by 25 per cent, the adjustment factor is [1.1/1.25] $=0.88$; that is, a decrease of 12 per cent in the ad valorem tariff rate due to the adjustment. For example, a tariff of 55 per cent is adjusted to a rate of 48.4 per cent.

For the one year 1930-31, the adjustment factor is [1.1/1.09] $=1.009$. No adjustment is made because the 10 per cent margin and the 9 per cent devaluation cancel out.

For the period before 1930-31 when the Australian pound was at parity with sterling, the old convention meant that more duty was collected on a given shipment at a given ad valorem rate than would have been collected under the current convention. The adjustment factor is [1.1/1], that is, an increase of 10 per cent. For example, a tariff rate of 10 per cent is adjusted to a tariff rate of 11 per cent.

(ii) The adjustment for the average tariff

The same adjustment factors are used for the average tariff rate. Before adjustment, the economy-wide average tariff rate before 1947 is defined as Duty Collected/Total Value of Imports (using the old convention), i.e.

$$
\overline{\mathrm{t}}=\sum_{i} \mathrm{~V}_{\mathrm{i}} \text {, pre-1947 } \mathrm{x} \mathrm{t}_{\mathrm{i}} \text {,pre - 1947 } / \sum_{i} \mathrm{~V}_{\mathrm{i}} \text {,pre-1947 }
$$

An adjustment is required because of the change in the method of valuation. The adjusted average tariff rate is the Duty Collected/ Total Value of Imports (using the current convention), i.e.

$$
\begin{aligned}
\mathrm{t}_{\mathrm{i}, \mathrm{adj}} & ={ }_{\mathrm{t}}^{-} \mathrm{x}\left[\mathrm{V}_{\text {pre-1947 }} / \mathrm{V}_{\text {post-1947 }}\right] \\
& =-\mathrm{t} \mathrm{x}[£ \operatorname{Stg}(1.1) / £ \mathrm{~A}]
\end{aligned}
$$

An equivalent method of making the adjustment is to take the Duty Collected (under the old convention) and divide by the total value of imports (under the old convention) adjusted for the method of valuation. For the period when the Australian pound was devalued vis-à-vis pound sterling by 25 per cent, the adjustment factor applied to the 
aggregate value of imports is $[1.25 / 1.1]=1.136$, that is, an increase of 13.6 per cent in the ad valorem tariff rate due to the adjustment.

The advantage of this method is that, in place of the adjustment factor of 0.88 , one can use the revaluations in terms of Australian currency of the Total Value of Imports which were made by the CBCS for the years 1938-39 to 1946-47 (see Introduction to the CBCS Overseas Trade Bulletin 1947-48, reproduced in CBCS, 1948). They made a more refined calculation, using the bilateral commercial exchange rates for each trading partner. They found an average adjustment of 13.8 per cent rather than 13.6 per cent. I have applied this CBCS factor to the reported value of aggregate imports for the years 1931-32 to 1946-47.

For the year 1930-31, no adjustment is made.

For the years 1903-04 to 1929-30, when the Australian pound was at parity with the pound sterling, the adjustment factor used is 1.1. This increases the average tariff compared to the official calculations because a given tariff rate at that time collected more revenue than the same rate would under the current convention due to the addition of the 10 per cent margin to fob values. 


\section{Appendix 3. Notes on the Calculation of the Average Tariff Series}

\section{Pre-CBCS}

For the years 1903, 1904 and 1905 data on imports and duty collected were compiled by the NSW Government Statistician under instructions from the Commonwealth Minister of Trade and Customs. The statistics of duty collected give a division between free and dutiable imports. This data is available in ABS historical microfiche series for ABS Catalogue No. 5409.0.

\section{CBSC/ABC period}

The CBCS and later its successor, the ABS, have collected data on the value of imports and the division between free and dutiable imports, and customs duty collected since 1906. The data is available in ABS historical microfiche series for ABS Catalogue No. 5409.0 until 1964-65, and afterwards in the Commonwealth Yearbooks, and from 198889 in the electronic series available from the ABS.

However, the required series cannot be obtained by just transcribing these values of duty collected and imports for each year and dividing. The value of imports is the value of merchandise imports, excluding the value of Specie and Bullion. The value of customs duty collected must be defined net of Refunds and Drawbacks, but including duty collected on dutiable ships' stores and miscellaneous customs duty. All of these items are sometimes included in the published totals and sometimes not. Care has been taken to trace a fully consistent series of customs duty collected, net of Refunds and Drawbacks but including duty collected on dutiable ships' stores and miscellaneous customs duty for all years.

There are breaks in these series in terms of timing and coverage. ABS statistics were reported on a calendar year basis from 1903 to 1913 but they have been presented on a financial year basis since 1914-15; there are no statistics reported for the first six months of 1914. The duty on ships' stores is not reported for 1923-34 and earlier years, resulting in a very slight understatement of the duty for these earlier years. Until 15 November 1947 all statistics of import trade were recorded in pounds sterling. Starting in 1988-89, 
the data is available in electronic form from the ABS with some difference in the treatment of refunds and drawbacks (see below). One of these discrepancies, the valuation change in 1947, affects the series significantly. This is discussed in Appendix 2.

\section{ABS electronic series}

In 1988-89 the ABS switched to electronic recording. I have obtained from the ABS an electronic copy of the annual revised series of Import Clearances and Duty paid on all imports, cross-classified by the rate of duty and type of imports (Normal, Concessional, Government) for the years 1988-89 to 2004-05. The averages calculated from these series can be compared with the averages calculated from the hard copy figures published for earlier years.

There are minor differences due to the different treatment of Refunds and Drawbacks in the electronic series. From 1988-89, there is no longer a series of refunds and drawbacks. The ABS receives a daily file from the Customs Department of all records cleared the previous day. These are kept for six months only. The daily file records any adjustments to a record previously lodged with Customs and the ABS records are amended as long as the original files are kept. Consequently, only those refunds and drawbacks which are recorded within six months of the original clearances are netted. Those refunds and drawbacks that take more than six months to be processed are not reflected in the ABS data. For this reason, there is a minor inconsistency between the pre-electronic and the post-electronic statistics, the latter overstating slightly the true value of net customs duty collected.

\section{Adjustments for Revenue duties}

Over the 50 year period, four different revenue duties have been levied for sub-periods. These duties are troublesome for the calculation of consistent series of average tariffs.

The four types are:

\section{$\underline{\text { Primage duties }}$}


Primage duties were introduced in 1930 and remained until the last primage duties were abolished on 1 January 1983. They were introduced as a revenue tax, mainly on luxury items. But they applied to imports of many goods produced in Australia as wells to some non-competitive imports and, for these goods, they provided additional protection. They were ad valorem duties and in the early part of our 50-year period the most common rate was 10 per cent. Goods which were the produce or manufacture of New Zealand, Fiji, Papua New Guinea and some other Pacific Islands were exempt and, therefore, the duties discriminated by source. From 1934 goods which were admitted at BP preferential rates for customs duties were subject to a reduced Primage rate of 5 per cent.

In the early 1950s Primage duties amounted to almost 10 per cent of the total duties including Primage and therefore added significantly to the levels of protection from the Australian Tariff. However, from the mid-Fifties, the number of tariff items on which Primage was levied was steadily reduced by the abolition of these duties or their incorporation in normal duties, and the rates were also lowered. By the mid-Sixties they amounted to only about 2 per cent of the total duties collected. To maintain a consistent series, it is essential that, for the years in which they applied, the revenue collected be incorporated in the statistics of total duty collected each year.

\section{2 per cent duty on items previously cleared free of duty}

For almost 9 years, from 1 July 1979 to 11 May 1988, many items previously cleared free of duty were subject to a 2 per cent duty. This was a revenue measure, announced in May before the 1979 Budget and removed in the Budget of 1988. During the period in which it applied, this tax collected on average around \$150 million each year. This amounted to about 7.5 per cent of total duty collected during the period.

\section{$\underline{3 \text { per cent duty on imported business inputs }}$}

Before the Budget of 1996 a 3 per cent tariff on imported business inputs which did not have a substitute manufactured in Australia was introduced, effective from 1 July 1996. This too was a revenue measure. However, there was an exemption for inputs used in the TCF, motor vehicle and food industries. The duty remained for 9 years until it was 
abolished in the Budget of 2005, effective from 11 May 2005, after a Productivity Commission Report (2000) had recommended its abolition. During the period in which it applied, this tax collected around \$200 million each year. This amounted to about 5 per cent of total duty collected during the period.

Both the 2 per cent and the 3 per cent duties were levied on non-competitive imported materials and inputs. These taxes raised the prices in Australia of the goods concerned but did not provide protection to Australian manufactures, indeed they reduced the effective rates of protection of those goods which used these inputs. The former effect imposes a welfare loss on the consumers of the products incorporating these inputs and the latter effect may have a positive or negative effect on welfare, depending chiefly on whether the user industries received above or below average levels of effective protection. The adjustments have been made each year by identifying, exactly or as closely as possible, the goods cleared and subject to these duties, and then subtracting the value of duty collected from the revenue tax in the numerator and subtracting the value of the dutiable imports on which these duties were levied in the denominator. I have calculated series of the average tariff for dutiable imports with and without the adjustment for these two revenue duties.

\section{(iv) Excise taxes}

An excise duty is a specific duty levied on the production or manufacture of certain goods in Australia. Three main groups of goods have been subject throughout the whole period to excise taxation; namely, alcoholic beverages excluding wine, tobacco products, and refined petroleum fuels. Excise duties are revenue taxes, levied on the so-called "sin goods". The rates of duties levied on these products have been very high when expressed in ad valorem terms. Goods which are excisable when produced in Australia are subject to customs duty when imported. For these goods, the customs duty is a specific tariff at a rate which is as higher than or as high as the excise duty rate on the corresponding imports. The difference between the tariff and the excise duty rate on each excisable good is the margin of nominal protection for the Australian producers concerned. When excise duty rates have been increased or decreased, the same adjustment has usually been made for the tariff on imports of equivalent goods. 
For the purposes of measuring the costs of protection, it is desirable to include only the margin of protection in the statistics of duty collected on excisable items and in the derivative statistics of average duties. However, all statistics of duty collected published by CBCS/ABS include the whole duty collected from the tariff rates on these items. All series derived from CBCS/ABS statistics of duty collected, therefore, overstate the rates of assistance to these excisable goods.

The only published study which has calculated the ad valorem equivalent nominal rates of assistance to excisable goods to my knowledge is the one I carried out for the years 1950-51 to 1971-72 (Lloyd, 1975), though the PC and its predecessors have included only the protective margin in their calculations of nominal rates of assistance to excisable goods. Lloyd found that the nominal rates of protection to excisable goods were generally high, with the solitary exception of Motor Spirits, compared to those due to tariffs on non-excisable goods. However, he also found this protective part was on average less than one quarter of the average customs duty on these goods; that is, over $3 / 4$ of the customs duty on these goods was a duty to match the rate of excise duty levied on excisable goods produced in Australia. Thus, the overstatement of the rates of assistance to these goods which results from using the CBCS/ABS statistics of customs duty collected was very great. In the 1980s and 1990s the rates of duty on Excise Equivalent goods were reduced to those applying to the equivalent exciseable goods, thus ending protection for this group of goods.

No adjustment has been made for this factor in the two series (outside the period after 1988-89 when electronic records are available). There are around 30-40 Excise Equivalent Goods among the tariff items in each year and a larger number of corresponding tariff items, whose descriptions and numbers change frequently. One would have to trace the specific excise and tariff rates for each item in each of the 100 years and then obtain the difference between the customs and excise duty rates which applied to each tariff item. Unfortunately, there is no correspondence between the goods which are subject to excise duties and those which are subject to customs duties. Even if we matched these items approximately, we would still need to calculate the difference between the customs and excise rates, multiply by the import quantities and divide by the value of imports for every one of dozens of items in every year. The amount of work required is prohibitive. 
Table 1. Passenger Motor Vehicles - Tariff Rates

\begin{tabular}{|c|c|c|c|}
\hline Year & BP Tariff rate & MFN Tariff Rate & $\begin{array}{l}\text { Av. Tariff } \\
+ \text { Primage }\end{array}$ \\
\hline & Percentage & Percentage & Percentage \\
\hline
\end{tabular}

Av. Tariff + Primage Adjusted for valuation Percentage

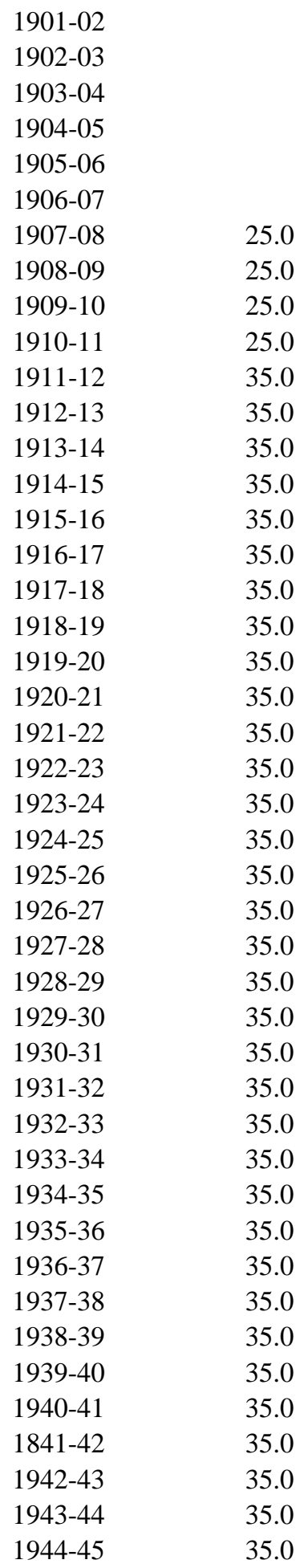

\begin{tabular}{|c|c|c|}
\hline 25.0 & 25.0 & 27.5 \\
\hline 25.0 & 25.0 & 27.5 \\
\hline 25.0 & 25.0 & 27.5 \\
\hline 25.0 & 25.0 & 27.5 \\
\hline 25.0 & 25.0 & 27.5 \\
\hline 25.0 & 25.0 & 27.5 \\
\hline 35.0 & 30.0 & 33.0 \\
\hline 35.0 & 30.0 & 33.0 \\
\hline 35.0 & 30.0 & 33.0 \\
\hline 35.0 & 30.0 & 33.0 \\
\hline 40.0 & 37.5 & 41.3 \\
\hline 40.0 & 37.5 & 41.3 \\
\hline 40.0 & 37.5 & 41.3 \\
\hline 45.0 & 37.5 & 41.3 \\
\hline 45.0 & 37.5 & 41.3 \\
\hline 45.0 & 37.5 & 41.3 \\
\hline 45.0 & 37.5 & 41.3 \\
\hline 45.0 & 37.5 & 41.3 \\
\hline 45.0 & 37.5 & 41.3 \\
\hline 55.0 & 45.0 & 49.5 \\
\hline 55.0 & 45.0 & 49.5 \\
\hline 55.0 & 45.0 & 49.5 \\
\hline 55.0 & 45.0 & 49.5 \\
\hline 55.0 & 45.0 & 49.5 \\
\hline 55.0 & 45.0 & 49.5 \\
\hline 55.0 & 45.0 & 49.5 \\
\hline 55.0 & 45.0 & 49.5 \\
\hline 55.0 & 45.0 & 49.5 \\
\hline 55.0 & 45.0 & 49.5 \\
\hline 55.0 & 49.0 & 49.0 \\
\hline 55.0 & 55.0 & 48.4 \\
\hline 55.0 & 52.5 & 46.2 \\
\hline 55.0 & 52.5 & 46.2 \\
\hline 55.0 & 52.5 & 46.2 \\
\hline 55.0 & 52.5 & 46.2 \\
\hline 55.0 & 52.5 & 46.2 \\
\hline 55.0 & 52.5 & 46.2 \\
\hline 55.0 & 52.5 & 46.2 \\
\hline 55.0 & 52.5 & 46.2 \\
\hline 55.0 & 52.5 & 46.2 \\
\hline 55.0 & 52.5 & 46.2 \\
\hline 55.0 & 52.5 & 46.2 \\
\hline 55.0 & 52.5 & 46.2 \\
\hline 55.0 & 52.5 & 46.2 \\
\hline
\end{tabular}




\begin{tabular}{|c|c|c|c|c|}
\hline 1945-46 & 35.0 & 55.0 & 52.5 & 46.2 \\
\hline 1946-47 & 35.0 & 55.0 & 52.5 & 46.2 \\
\hline $1947-48$ & 22.5 & 47.5 & 42.5 & 42.5 \\
\hline 1948-49 & 22.5 & 47.5 & 42.5 & 42.5 \\
\hline 1949-50 & 22.5 & 47.5 & 42.5 & 42.5 \\
\hline 1950-51 & 22.5 & 47.5 & 42.5 & 42.5 \\
\hline 1951-52 & 22.5 & 47.5 & 42.5 & 42.5 \\
\hline $1952-53$ & 22.5 & 47.5 & 42.5 & 42.5 \\
\hline $1953-54$ & 22.5 & 47.5 & 42.5 & 42.5 \\
\hline 1954-55 & 22.5 & 47.5 & 42.5 & 42.5 \\
\hline $1955-56$ & 22.5 & 47.5 & 42.5 & 42.5 \\
\hline $1956-57$ & 22.5 & 47.5 & 42.5 & 42.5 \\
\hline 1957-58 & 22.5 & 47.5 & 42.5 & 42.5 \\
\hline 1958-59 & 25.0 & 35.0 & 37.3 & 37.3 \\
\hline 1959-60 & 25.0 & 35.0 & 37.6 & 37.6 \\
\hline 1960-61 & 25.0 & 35.0 & 37.4 & 37.4 \\
\hline 1961-62 & 25.0 & 35.0 & 38.0 & 38.0 \\
\hline $1962-63$ & 25.0 & 35.0 & 39.3 & 39.3 \\
\hline 1963-64 & 25.0 & 35.0 & 40.0 & 40.0 \\
\hline 1964-65 & 25.0 & 35.0 & 33.2 & 33.2 \\
\hline 1965-66 & 25.0 & 35.0 & 33.8 & 33.8 \\
\hline 1966-67 & 35.0 & 45.0 & 43.4 & 43.4 \\
\hline 1967-68 & 35.0 & 45.0 & 44.4 & 44.4 \\
\hline 1968-69 & 35.0 & 45.0 & 43.9 & 43.9 \\
\hline 1969-70 & 35.0 & 45.0 & 43.5 & 43.5 \\
\hline 1970-71 & 35.0 & 45.0 & 44.0 & 44.0 \\
\hline $1971-72$ & 35.0 & 45.0 & 44.4 & 44.4 \\
\hline 1972-73 & 35.0 & 45.0 & 44.9 & 44.9 \\
\hline 1973-74 & 26.0 & 33.8 & 33.9 & 33.9 \\
\hline 1974-75 & & 45.0 & 45.0 & 45.0 \\
\hline 1975-76 & & 45.0 & 45.0 & 45.0 \\
\hline 1976-77 & & 45.0 & 45.0 & 45.0 \\
\hline $1977-78$ & & 45.0 & 45.0 & 45.0 \\
\hline 1978-79 & & 57.5 & 57.5 & 57.5 \\
\hline 1979-80 & & 57.5 & 57.5 & 57.5 \\
\hline 1980-81 & & 57.5 & 57.5 & 57.5 \\
\hline 1981-82 & & 57.5 & 57.5 & 57.5 \\
\hline 1982-83 & & 57.5 & 57.5 & 57.5 \\
\hline 1983-84 & & 57.5 & 57.5 & 57.5 \\
\hline 1984-85 & & 57.5 & 57.5 & 57.5 \\
\hline 1985-86 & & 57.5 & 57.5 & 57.5 \\
\hline 1986-87 & & 57.5 & 57.5 & 57.5 \\
\hline 1987-88 & & 57.5 & 57.5 & 57.5 \\
\hline 1987-89 & & 45.0 & 45.0 & 45.0 \\
\hline 1999-90 & & 42.5 & 42.5 & 42.5 \\
\hline 1990-91 & & 40.0 & 40.0 & 40.0 \\
\hline 1991-92 & & 37.5 & 37.5 & 37.5 \\
\hline 1992-93 & & 35.0 & 35.0 & 35.0 \\
\hline 1993-94 & & 32.5 & 32.5 & 32.5 \\
\hline 1994-95 & & 30.0 & 30.0 & 30.0 \\
\hline 1995-96 & & 27.5 & 27.5 & 27.5 \\
\hline 1996-97 & & 25.0 & 25.0 & 25.0 \\
\hline $1997-98$ & & 22.5 & 22.5 & 22.5 \\
\hline 1997-99 & & 20.0 & 20.0 & 20.0 \\
\hline
\end{tabular}


1999-00

2000-01

2001-02

2002-03

2003-04

2004-05
17.5

15.0

15.0

15.0

15.0

10.0
17.5

15.0

15.0

15.0

15.0

10.0
17.5

15.0

15.0

15.0

15.0

10.0 
Table 2. Blankets - Tariff Rates

\begin{tabular}{|c|c|c|c|c|c|}
\hline Year & BP Tariff Rate & $\begin{array}{l}\text { MFN Tariff } \\
\text { Rate }\end{array}$ & $\begin{array}{l}\text { Average } \\
\text { Tariff }\end{array}$ & $\begin{array}{l}\text { Av. Tariff } \\
\text { +Primage }\end{array}$ & $\begin{array}{l}\text { Av. Tariff + Primage } \\
\text { Adjusted for valuation, }\end{array}$ \\
\hline & Percentage & Percentage & Percentage & Percentage & Percentage \\
\hline
\end{tabular}

1901-02

$\begin{array}{lll}15.0 & 15.0 & 15.0\end{array}$

16.5

1902-03

15.0

$15.0 \quad 15.0$

16.5

1903-04

15.0

$15.0 \quad 15.0$

16.5

1904-05

15.0

15.0

15.0

16.5

1905-06

15.0

15.0

15.0

16.5

1906-07

15.0

15.0

15.0

16.5

1907-08

25.0

30.0

27.5

27.5

30.3

1908-09

30.0

27.5

27.5

30.3

25.0

27.5

27.5

30.3

1910-11

30.0

27.5

27.5

30.3

$\begin{array}{ll}25.0 & 30.0 \\ 25.0 & 30.0\end{array}$

27.5

27.5

30.3

1912-13

25.0

27.5

27.5

30.3

1913-14

25.0

27.5

27.5

30.3

1914-15

25.0

27.5

27.5

30.3

1915-16

25.0

27.5

27.5

30.3

1916-17

25.0

27.5

27.5

30.3

1917-18

25.0

27.5

27.5

30.3

1918-19

1919-20

25.0

27.5

27.5

30.3

25.0

27.5

27.5

30.3

1920-21

25.0

27.5

27.5

30.3

1921-22

25.0

32.5

32.5

35.8

1922-23

25.0

32.5

32.5

35.8

1923-24

25.0

32.5

32.5

35.8

1924-25

25.0

32.5

32.5

35.8

1925-26

25.0

32.5

32.5

35.8

1927-28

25.0

32.5

32.5

35.8

1928-29

25.0

$\begin{array}{ll}40.0 & 32.5 \\ 40.0 & 32.5\end{array}$

32.5

35.8

35.8

25.0

32.5

35.8

1930-31

25.0

32.5

32.5

36.5

1931-32

25.0

32.5

36.5

42.5

37.4

55.0

45.0

52.5

46.2

35.0

45.0

52.5

46.2

1934-35

35.0

55.0

52.5

46.2

33.3

40.8

35.9

1936-37

20.0

46.3

33.3

40.8

35.9

1937-38

20.0

33.3

40.8

35.9

46.3

33.3

40.8

35.9

1939-40

20.0

33.3

40.8

35.9

20.0

33.3

40.8

35.9

1841-42

46.3

33.3

40.8

20.0

46.3

40.8 


\begin{tabular}{|c|c|c|c|c|c|}
\hline 1944-45 & 20.0 & 46.3 & 33.3 & 40.8 & 35.9 \\
\hline 1945-46 & 20.0 & 46.3 & 33.3 & 40.8 & 35.9 \\
\hline 1946-47 & 20.0 & 46.3 & 33.3 & 40.8 & 35.9 \\
\hline $1947-48$ & 17.5 & 32.5 & 25.0 & 32.3 & 32.3 \\
\hline 1948-49 & 17.5 & 32.5 & 25.0 & 32.3 & 32.3 \\
\hline 1949-50 & 17.5 & 32.5 & 25.0 & 32.3 & 32.3 \\
\hline $1950-51$ & 17.5 & 32.5 & 25.0 & 32.3 & 32.3 \\
\hline 1951-52 & 17.5 & 32.5 & 25.0 & 32.3 & 32.3 \\
\hline 1952-53 & 17.5 & 32.5 & 25.0 & 32.3 & 32.3 \\
\hline $1953-54$ & 17.5 & 32.5 & 25.0 & 32.3 & 32.3 \\
\hline 1954-55 & 17.5 & 32.5 & 25.0 & 32.3 & 32.3 \\
\hline $1955-56$ & 17.5 & 32.5 & 25.0 & 32.3 & 32.3 \\
\hline $1956-57$ & 17.5 & 32.5 & 25.0 & 32.3 & 32.3 \\
\hline $1957-58$ & 17.5 & 32.5 & 25.0 & 32.3 & 32.3 \\
\hline 1958-59 & 17.5 & 32.5 & 25.0 & 32.3 & 32.3 \\
\hline 1959-60 & 17.5 & 32.5 & 25.0 & 32.3 & 32.3 \\
\hline 1960-61 & 17.5 & 32.5 & 25.0 & 32.3 & 32.3 \\
\hline 1961-62 & 17.5 & 32.5 & 25.0 & 32.3 & 32.3 \\
\hline $1962-63$ & 17.5 & 32.5 & 25.0 & 32.3 & 32.3 \\
\hline $1963-64$ & 17.5 & 32.5 & 25.0 & 32.3 & 32.3 \\
\hline 1964-65 & 17.5 & 40.0 & 28.8 & 32.3 & 32 \\
\hline 1965-66 & 17.5 & 40.0 & 28.8 & 28.8 & 28 \\
\hline 1966-67 & 17.5 & 40.0 & 28.8 & 28.8 & 28 \\
\hline $1967-68$ & 17.5 & 40.0 & 28.8 & 28.8 & 28 \\
\hline 1968-69 & 20.0 & 35.0 & 27.8 & 27.8 & 27 \\
\hline 1969-70 & 20.0 & 35.0 & 27.8 & 27.8 & 27 \\
\hline 1970-71 & 20.0 & 35.0 & 27.8 & 27.8 & 27 \\
\hline 1971-72 & 20.0 & 35.0 & 27.8 & 27.8 & 27 \\
\hline $1972-73$ & 20.0 & 35.0 & 27.8 & 27.8 & 27.8 \\
\hline $1973-74$ & 15.0 & 26.0 & 27.8 & 27.8 & 27.8 \\
\hline 1974-75 & 15.0 & 26.0 & 27.8 & 27.8 & 27.8 \\
\hline $1975-76$ & 15.0 & 26.0 & 27.8 & 27.8 & 27.8 \\
\hline 1976-77 & 15.0 & 26.0 & 27.8 & 27.8 & 27.8 \\
\hline 1977-78 & 15.0 & 26.0 & 27.8 & 27.8 & 27.8 \\
\hline $1967-79$ & 15.0 & 26.0 & 27.8 & 27.8 & 27.8 \\
\hline 1979-80 & 15.0 & 26.0 & 27.8 & 27.8 & 27.8 \\
\hline $1980-81$ & & 26.0 & 26.0 & 26.0 & 26.0 \\
\hline 1981-82 & & 26.0 & 26.0 & 26.0 & 26.0 \\
\hline 1982-83 & & 50.0 & 50.0 & 50.0 & 50.0 \\
\hline 1983-84 & & 45.0 & 45.0 & 45.0 & 45 \\
\hline 1984-85 & & 45.0 & 45.0 & 45.0 & 45.0 \\
\hline 1985-86 & & 45.0 & 45.0 & 45.0 & 45 \\
\hline 1986-87 & & 45.0 & 45.0 & 45.0 & 45.0 \\
\hline $1987-88$ & & 40.0 & 40.0 & 40.0 & 40 \\
\hline $1987-89$ & & 40.0 & 40.0 & 40.0 & 40 \\
\hline $1999-90$ & & 37.5 & 37.5 & 37.5 & 37 \\
\hline $1990-91$ & & 35.0 & 35.0 & 35.0 & 35 \\
\hline $1991-92$ & & 35.0 & 35.0 & 35.0 & 35 \\
\hline $1992-93$ & & 29.0 & 29.0 & 29.0 & 29 \\
\hline $1993-94$ & & 27.0 & 27.0 & 27.0 & \\
\hline $1994-95$ & & 25.0 & 25.0 & 25.0 & 25 \\
\hline $1995-96$ & & 23.0 & 23.0 & 23.0 & 23 \\
\hline $1996-97$ & & 23.0 & 23.0 & 23.0 & \\
\hline $1997-98$ & & 21.0 & 21.0 & 21.0 & \\
\hline
\end{tabular}


1997-99

1999-00

2000-01

2001-02

2002-03

2003-04

2004-05
19.0

17.0

15.0

15.0

15.0

15.0

10.0
19.0

17.0

15.0

15.0

15.0

15.0

10.0
19.0

17.0

15.0

15.0

15.0

15.0

10.0
19.0

17.0

15.0

15.0

15.0

15.0

10.0 


\begin{tabular}{|c|c|c|c|c|c|}
\hline & & Table 3 Beer & Customs anc & xcise duties & \\
\hline & Excise & Customs & Ad valorem & & \\
\hline & Duty & Duty & Equivalent & Rates & \\
\hline Year & \$/litre & \$/litre & Customs & Average Rate of & ARP + Primage \\
\hline & & & Duty & & \\
\hline & & & Rate & Protection & \\
\hline & & & $\%$ & $\%$ & $\%$ \\
\hline 1901-02 & 0.0055 & 0.0055 & & 0.0 & 0.0 \\
\hline 1902-03 & 0.0055 & 0.0055 & & 0.0 & 0.0 \\
\hline 1903-04 & 0.0055 & 0.0055 & 7.2 & 0.0 & 0.0 \\
\hline 1904-05 & 0.0055 & 0.0055 & 7.3 & 0.0 & 0.0 \\
\hline 1905-06 & 0.0055 & 0.0055 & 7.4 & 0.0 & 0.0 \\
\hline 1906-07 & 0.0055 & 0.0055 & 7.3 & 0.0 & 0.0 \\
\hline 1907-08 & 0.0055 & 0.0330 & 7.1 & 0.0 & 0.0 \\
\hline 1908-09 & 0.0055 & 0.0330 & 43.6 & 36.3 & 36.3 \\
\hline 1909-10 & 0.0055 & 0.0330 & 44.9 & 37.4 & 37.4 \\
\hline $1910-11$ & 0.0055 & 0.0330 & 45.5 & 37.9 & 37.9 \\
\hline 1911-12 & 0.0055 & 0.0330 & 46.0 & 38.3 & 38.3 \\
\hline 1912-13 & 0.0055 & 0.0330 & 46.3 & 38.5 & 38.5 \\
\hline 1913-14 & 0.0055 & 0.0330 & 46.0 & 38.3 & 38.3 \\
\hline 1914-15 & 0.0110 & 0.0550 & 60.2 & 45.1 & 45.1 \\
\hline 1915-16 & 0.0110 & 0.0550 & 56.8 & 42.6 & 42.6 \\
\hline 1916-17 & 0.0110 & 0.0550 & 46.5 & 34.9 & 34.9 \\
\hline 1917-18 & 0.0128 & 0.0550 & 32.6 & 22.8 & 22.8 \\
\hline 1918-19 & 0.0220 & 0.0605 & 31.0 & 17.2 & 17.2 \\
\hline 1919-20 & 0.0220 & 0.0605 & 27.2 & 15.1 & 15.1 \\
\hline $1920-21$ & 0.0385 & 0.0770 & 32.6 & 13.6 & 13.6 \\
\hline $1921-22$ & 0.0385 & 0.0770 & 33.0 & 13.7 & 13.7 \\
\hline $1922-23$ & 0.0385 & 0.0770 & 36.0 & 15.0 & 15.0 \\
\hline $1923-24$ & 0.0385 & 0.0770 & 40.3 & 16.8 & 16.8 \\
\hline $1924-25$ & 0.0385 & 0.0770 & 39.9 & 16.6 & 16.6 \\
\hline $1925-26$ & 0.0385 & 0.0770 & 40.0 & 16.7 & 16.7 \\
\hline 1926-27 & 0.0385 & 0.0770 & 41.2 & 17.1 & 17.1 \\
\hline $1927-28$ & 0.0385 & 0.0770 & 40.0 & 16.7 & 16.7 \\
\hline $1928-29$ & 0.0385 & 0.0770 & 40.3 & 16.8 & 16.8 \\
\hline 1929-30 & 0.0403 & 0.0770 & 39.1 & 13.0 & 13.0 \\
\hline $1930-31$ & 0.0440 & 0.0770 & 38.2 & 12.7 & 16.7 \\
\hline $1931-32$ & 0.0440 & 0.0770 & 45.0 & 15.0 & 20.0 \\
\hline $1932-33$ & 0.0440 & 0.1430 & 45.9 & 21.2 & 26.2 \\
\hline $1933-34$ & 0.0385 & 0.1430 & 43.6 & 20.1 & 25.1 \\
\hline $1934-35$ & 0.0385 & 0.1430 & 40.9 & 17.0 & 22.0 \\
\hline $1935-36$ & 0.0385 & 0.1430 & 53.4 & 22.2 & 27.2 \\
\hline $1936-37$ & 0.0385 & 0.1430 & 59.3 & 24.7 & 29.7 \\
\hline $1937-38$ & 0.0385 & 0.1375 & 57.5 & 23.9 & 28.9 \\
\hline 1938-39 & 0.0385 & 0.1375 & 58.1 & 19.4 & 24.4 \\
\hline $1939-40$ & 0.0440 & 0.1430 & 58.5 & 22.5 & 27.5 \\
\hline 1940-41 & 0.0605 & 0.1430 & 66.7 & 20.8 & 25.8 \\
\hline 1941-42 & 0.0660 & 0.1430 & 64.7 & 16.2 & 21.2 \\
\hline $1942-43$ & 0.1007 & 0.1430 & 104.2 & 22.3 & 27.3 \\
\hline 1943-44 & 0.1007 & 0.1430 & 118.7 & 25.4 & 30.4 \\
\hline
\end{tabular}

ARP + Primage Adjusted for method of valuation 


\begin{tabular}{|c|c|c|c|c|c|}
\hline 1944-45 & 0.1007 & 0.1430 & 118.7 & 25.4 & 30.4 \\
\hline 1945-46 & 0.1007 & 0.2180 & 82.0 & 17.1 & 22.1 \\
\hline 1946-47 & 0.1007 & 0.2180 & 80.3 & 17.5 & 22.5 \\
\hline $1947-48$ & 0.1007 & 0.2180 & 74.3 & 15.9 & 20.9 \\
\hline 1948-49 & 0.1007 & 0.2180 & 92.1 & 18.7 & 23.7 \\
\hline $1949-50$ & 0.1007 & 0.2180 & 90.7 & 20.1 & 25.1 \\
\hline $1950-51$ & 0.1007 & 0.2180 & 91.4 & 21.2 & 26.2 \\
\hline $1951-52$ & 0.1575 & 0.2567 & 137.2 & 19.9 & 24.9 \\
\hline $1952-53$ & 0.1575 & 0.2567 & 147.1 & 29.4 & 34.4 \\
\hline $1953-54$ & 0.1575 & 0.2567 & 112.4 & 20.9 & 25.9 \\
\hline 1954-55 & 0.1575 & 0.2567 & 88.7 & 14.1 & 19.1 \\
\hline $1955-56$ & 0.1575 & 0.2567 & 90.3 & 17.1 & 22.1 \\
\hline $1956-57$ & 0.2162 & 0.3152 & 111.2 & 13.0 & 18.0 \\
\hline $1957-58$ & 0.2162 & 0.3152 & 111.1 & 12.9 & 17.9 \\
\hline 1958-59 & 0.2162 & 0.3152 & 112.2 & 12.8 & 17.8 \\
\hline $1959-60$ & 0.2162 & 0.3152 & 111.2 & 12.9 & 17.9 \\
\hline $1960-61$ & 0.2162 & 0.3152 & 113.5 & 13.9 & 18.9 \\
\hline 1961-62 & 0.2162 & 0.3152 & 111.4 & 15.3 & 20.3 \\
\hline $1962-63$ & 0.2162 & 0.3152 & 109.0 & 14.0 & 19.0 \\
\hline $1963-64$ & 0.2162 & 0.3152 & 110.5 & 14.4 & 19.4 \\
\hline 1964-65 & 0.2162 & 0.3152 & 114.3 & 19.3 & 19.3 \\
\hline $1965-66$ & 0.2501 & 0.2675 & 127.3 & 18.4 & 18.4 \\
\hline 1966-67 & 0.2501 & 0.3013 & 122.0 & 19.6 & 19.6 \\
\hline 1967-68 & 0.2501 & 0.3013 & 119.2 & 19.3 & 19.3 \\
\hline 1968-69 & 0.2501 & 0.3013 & 111.3 & 15.7 & 15.7 \\
\hline 1969-70 & 0.2501 & 0.3013 & 111.9 & 15.9 & 15.9 \\
\hline $1970-71$ & 0.2501 & 0.3013 & 103.8 & 13.4 & 13.4 \\
\hline 1971-72 & 0.2501 & 0.3013 & 101.8 & 13.4 & 13.4 \\
\hline $1972-73$ & 0.2500 & 0.3000 & 99.3 & 12.7 & 12.7 \\
\hline 1973-74 & 0.2500 & 0.3000 & 97.3 & 12.8 & 12.8 \\
\hline $1974-75$ & 0.2500 & 0.3000 & 89.3 & 12.8 & 12.8 \\
\hline $1975-76$ & 0.3700 & 0.3000 & 99.6 & 9.7 & 9.7 \\
\hline 1976-77 & 0.3900 & 0.4410 & 79.5 & 7.4 & 7.4 \\
\hline $1977-78$ & 0.3900 & 0.4210 & 73.1 & 5.2 & 5.2 \\
\hline $1967-79$ & 0.5200 & 0.5470 & 88.7 & 4.1 & 4.1 \\
\hline 1979-80 & 0.5200 & 0.5470 & 83.5 & 3.1 & 3.1 \\
\hline $1980-81$ & 0.5200 & 0.5470 & 83.5 & 3.1 & 3.1 \\
\hline 1981-82 & 0.5200 & 0.5470 & & 3.1 & 3.1 \\
\hline $1982-83$ & 0.6000 & 0.6270 & & 3.1 & 3.1 \\
\hline 1983-84 & 0.6400 & 0.6570 & & 0.0 & 0.0 \\
\hline 1984-85 & 0.6600 & 0.6600 & & 0.0 & 0.0 \\
\hline 1985-86 & 0.7000 & 0.7000 & & 0.0 & 0.0 \\
\hline 1986-87 & 0.7600 & 0.7600 & & 0.0 & 0.0 \\
\hline $1987-88$ & 0.8200 & 0.8200 & & 0.0 & 0.0 \\
\hline 1988-89 & & & & 0.0 & 0.0 \\
\hline 1999-90 & & & & 0.0 & 0.0 \\
\hline 1990-91 & & & & 0.0 & 0.0 \\
\hline 1991-92 & & & & 0.0 & 0.0 \\
\hline 1992-93 & & & & 0.0 & 0.0 \\
\hline 1993-94 & & & & 0.0 & 0.0 \\
\hline 1994-95 & & & & 0.0 & 0.0 \\
\hline 1995-96 & & & & 0.0 & 0.0 \\
\hline 1996-97 & & & & 0.0 & 0.0 \\
\hline 1997-98 & & & & 0.0 & 0.0 \\
\hline
\end{tabular}

26.

19.

19.

20.

23.

25.

26.

24.

34.

19.

22.

18.

17.

17.

17.

18

20.

19.

19.

19.

18.

19.

19.

15.

15.

13.

13.

12.

12.

12.

9.

7.

5

4.

3.

3.

3.

3.

0.

0.

0.

0

0

0

0

0 .

0.

0.

0. 
1997-99

1999-00

2000-01

2001-02

2002-03

2003-04

2004-05
0.0

0.0

0.0

0.0

0.0

0.0

0.0
0.0

0.0

0.0

0.0

0.0

0.0

0.0
0.1

0.1

0.

0.1

0.

0

0.1 
Table 4

Table 4. Estimates of the Average Duty on All Imports, Australia, 1988-89 to 2004-05 Financial years

\begin{tabular}{|c|c|c|c|}
\hline & AM & AM excise-adjusted & TRI excise-adjusted \\
\hline 1988-89 & 8.3 & 7.0 & 16.9 \\
\hline 1989-90 & 8.0 & 6.6 & 16.7 \\
\hline 1990-91 & 7.3 & 5.9 & 16.3 \\
\hline 1991-92 & 6.9 & 5.5 & 14.5 \\
\hline 1992-93 & 6.0 & 4.9 & 12.5 \\
\hline 1993-94 & 5.4 & 4.6 & 12.1 \\
\hline 1994-95 & 4.9 & 4.3 & 11.4 \\
\hline 1995-96 & 4.3 & 3.6 & 10.3 \\
\hline 1996-97 & 4.4 & 3.5 & 9.4 \\
\hline 1997-98 & 4.4 & 3.5 & 8.7 \\
\hline 1998-99 & 4.1 & 3.2 & 7.8 \\
\hline $1999-00$ & 3.7 & 2.8 & 6.8 \\
\hline 2000-01 & 4.0 & 2.9 & 6.7 \\
\hline 2001-02 & 4.0 & 3.1 & 6.9 \\
\hline 2002-03 & 3.9 & 3.1 & 7.0 \\
\hline 2003-04 & 3.9 & 3.2 & 7.1 \\
\hline 2004-05 & 3.5 & 2.7 & 5.9 \\
\hline
\end{tabular}


Table 5. Average Duty

1903-04 to 2004-05

$\begin{array}{ccc}\text { Financial Year } & \begin{array}{c}\text { Average duty } \\ \text { (Customs Plus } \\ \text { Primage, Net) - } \\ \text { All Clearances }\end{array} & \begin{array}{c}\text { Average duty } \\ \text { (Customs Plus } \\ \text { Primage, Net) - } \\ \text { Dutiable clearances } \\ \text { only, Adjusted for } \\ \end{array} \\ & \text { revenue duties }\end{array}$

1903 - 1904

1904 - 1905

1905 - 1906

1906 - 1907

1907 - 1908

1908 - 1909

1909 - 1910

1910 - 1911

1911 - 1912

1912 - 1913

1913 - 1914

1914 - 1915

1915 - 1916

1916 - 1917

1917 - 1918

1918 - 1919

1919 - 1920

1920 - 1921

1921 - 1922

1922 - 1923

1923 - 1924

1924 - 1925

1925 - 1926

1926 - 1927

1927 - 1928

1928 - 1929

1929 - 1930

1930 - 1931

1931 - 1932

1932 - 1933

1933 - 1934

1934 - 1935

1935 - 1936
21.1

19.7

18.4

17.1

17.2

18.2

17.8

17.0

16.8

17.1

16.0

19.0

17.6

16.1

15.6

12.1

13.8

13.2

16.8

17.1

17.9

18.0

18.6

19.4

20.3

20.6

23.1

30.1

42.2

37.5

37.4

34.9

33.6
Average duty (Customs Plus Primage, Net) All clearances Adjusted for method of valuation

Percentage of
Clearances
entering duty
Average duty free, adjusted
(Customs Plus
Primage, Net)
- Dutiable
clearances
Only,
Adjusted for
Revenue
duties
+ Method of
valuation

23.2

21.7

20.3

18.9

18.9

20.1

19.5

18.7

18.5

18.8

17.6

20.9

19.4

17.7

17.1

13.3

15.2

14.6

18.4

18.8

19.7

19.8

20.4

21.3

22.3

22.7

25.4

30.1

37.1

33.0

33.0

30.7

29.6

$\begin{array}{ll}32.6 & 28.8 \\ 31.7 & 31.4 \\ 30.8 & 34.0 \\ 29.4 & 35.7 \\ 28.8 & 34.4 \\ 33.7 & 40.4 \\ 33.5 & 41.7 \\ 33.3 & 43.8 \\ 31.5 & 41.1 \\ 30.6 & 38.5 \\ 30.9 & 42.9 \\ 31.6 & 33.9 \\ 28.1 & 31.0 \\ 27.5 & 35.5 \\ 22.8 & 24.8 \\ 21.8 & 38.7 \\ 24.8 & 38.9 \\ 23.5 & 38.1 \\ 29.4 & 37.3 \\ 28.2 & 33.2 \\ 28.4 & 30.7 \\ 30.0 & 34.0 \\ 32.2 & 36.6 \\ 33.4 & 36.1 \\ 35.0 & 36.2 \\ 36.2 & 37.4 \\ 43.2 & 41.3 \\ 52.2 & 42.3 \\ 63.4 & 41.4 \\ 57.2 & 42.3 \\ 56.0 & 41.2 \\ 50.8 & 39.5 \\ 48.6 & 39.1 \\ & \end{array}$

28.8

34.0

35.7

34.4

41.7

43.8

41.1

38.5

42.9

33.9

31.0

35.5

38.7

38.9

38.1

37.3

3.2

34.0

36.6

36.1

36.2

37.4

41.3

42.3

41.4

42.3

39.5

39.1 


\begin{tabular}{|c|c|c|c|c|}
\hline 1936 - 1937 & 31.8 & 54.4 & 28.0 & 47.9 \\
\hline 1937 - 1938 & 29.5 & 48.8 & 26.0 & 43.0 \\
\hline 1938 - 1939 & 31.4 & 55.6 & 27.6 & 48.9 \\
\hline 1939 - 1940 & 29.8 & 52.8 & 26.3 & 46.5 \\
\hline 1940 - 1941 & 25.0 & 60.4 & 22.0 & 53.2 \\
\hline 1941 - 1942 & 16.0 & 47.4 & 14.1 & 41.7 \\
\hline 1942 - 1943 & 9.3 & 51.8 & 8.2 & 45.6 \\
\hline $1943-1944$ & 9.4 & 52.2 & 8.3 & 46.0 \\
\hline 1944 - 1945 & 9.8 & 54.8 & 8.6 & 48.2 \\
\hline 1945 - 1946 & 18.2 & 47.1 & 16.0 & 41.4 \\
\hline 1946 - 1947 & 24.8 & 46.9 & 21.8 & 41.3 \\
\hline 1947 - 1948 & 17.0 & 29.7 & 17.0 & 29.7 \\
\hline 1948 - 1949 & 15.3 & 27.0 & 15.3 & 27.0 \\
\hline $1949-1950$ & 14.5 & 26.2 & 14.5 & 26.2 \\
\hline 1950 - 1951 & 12.4 & 24.5 & 12.4 & 24.5 \\
\hline 1951 - 1952 & 10.9 & 23.0 & 10.9 & 23.0 \\
\hline $1952-1953$ & 13.9 & 33.9 & 13.9 & 33.9 \\
\hline 1953 - 1954 & 14.0 & 26.3 & 14.0 & 26.3 \\
\hline 1954 - 1955 & 12.0 & 22.9 & 12.0 & 22.9 \\
\hline 1955 - 1956 & 10.7 & 22.0 & 10.7 & 22.0 \\
\hline 1956 - 1957 & 9.6 & 21.9 & 9.6 & 21.9 \\
\hline 1957 - 1958 & 9.1 & 19.8 & 9.1 & 19.8 \\
\hline 1958 - 1959 & 9.0 & 21.7 & 9.0 & 21.7 \\
\hline 1959 - 1960 & 9.1 & 21.2 & 9.1 & 21.2 \\
\hline 1960 - 1961 & 9.4 & 20.0 & 9.4 & 20.0 \\
\hline 1961 - 1962 & 9.6 & 22.1 & 9.6 & 22.1 \\
\hline 1962 - 1963 & 9.7 & 22.0 & 9.7 & 22.0 \\
\hline 1963 - 1964 & 9.8 & 22.3 & 9.8 & 22.3 \\
\hline 1964 - 1965 & 9.8 & 22.9 & 9.8 & 22.9 \\
\hline 1965 - 1966 & 9.3 & 22.0 & 9.3 & 22.0 \\
\hline 1966 - 1967 & 9.1 & 22.4 & 9.1 & 22.4 \\
\hline 1967 - 1968 & 9.6 & 22.8 & 9.6 & 22.8 \\
\hline 1968 - 1969 & 10.1 & 23.0 & 10.1 & 23.0 \\
\hline 1969 - 1970 & 10.7 & 23.3 & 10.7 & 23.3 \\
\hline 1970 - 1971 & 12.4 & 25.5 & 12.4 & 25.5 \\
\hline 1971 - 1972 & 12.9 & 26.6 & 12.9 & 26.6 \\
\hline 1972 - 1973 & 13.2 & 30.1 & 13.2 & 30.1 \\
\hline $1973-1974$ & 10.4 & 26.8 & 10.4 & 26.8 \\
\hline $1974-1975$ & 10.8 & 28.6 & 10.8 & 28.6 \\
\hline 1975 - 1976 & 11.7 & 29.7 & 11.7 & 29.7 \\
\hline 1976 - 1977 & 11.5 & 29.4 & 11.5 & 29.4 \\
\hline 1977 - 1978 & 10.4 & 29.0 & 10.4 & 29.0 \\
\hline 1978 - 1979 & 10.2 & 31.3 & 10.2 & 31.3 \\
\hline 1979 - 1980 & 9.9 & 28.8 & 9.9 & 28.8 \\
\hline 1980 - 1981 & 9.7 & 28.4 & 9.7 & 28.4 \\
\hline 1981 - 1982 & 9.2 & 27.7 & 9.2 & 27.7 \\
\hline 1982 - 1983 & 9.5 & 28.1 & 9.5 & 28.1 \\
\hline 1983 - 1984 & 9.9 & 27.0 & 9.9 & 27.0 \\
\hline 1984 - 1985 & 10.0 & 27.0 & 10.0 & 27.0 \\
\hline 1985 - 1986 & 9.6 & 26.3 & 9.6 & 26.3 \\
\hline 1986 - 1987 & 8.7 & 24.8 & 8.7 & 24.8 \\
\hline 1987 - 1988 & 8.9 & 24.3 & 8.9 & 24.3 \\
\hline 1988 - 1989 & 8.3 & 23.5 & 8.3 & 23.5 \\
\hline 1989 - 1990 & 8.0 & 22.9 & 8.0 & 22.9 \\
\hline
\end{tabular}




$\begin{array}{lccccc}1990-1991 & 7.3 & 21.3 & 7.3 & 21.3 & 65.8 \\ 1991-1992 & 6.9 & 20.4 & 6.9 & 20.4 & 66.3 \\ 1992-1993 & 6.0 & 18.9 & 6.0 & 18.9 & 68.1 \\ 1993-1994 & 5.4 & 17.1 & 5.4 & 17.1 & 68.4 \\ 1994-1995 & 4.9 & 16.1 & 4.9 & 16.1 & 69.3 \\ 1995-1996 & 4.3 & 14.7 & 4.3 & 14.7 & 70.7 \\ 1996-1997 & 4.4 & 12.2 & 4.4 & 12.2 & 65.9 \\ 1997-1998 & 4.4 & 11.3 & 4.4 & 11.3 & 63.4 \\ 1998-1999 & 4.1 & 10.9 & 4.1 & 10.9 & 64.4 \\ 1999-2000 & 3.7 & 10.6 & 3.7 & 10.6 & 67.0 \\ 2000-2001 & 4.0 & 11.2 & 4.0 & 11.2 & 65.9 \\ 2001-2002 & 4.0 & 10.4 & 4.0 & 10.4 & 63.3 \\ 2002-2003 & 3.9 & 10.0 & 3.9 & 10.0 & 63.2 \\ 2003-2004 & 3.9 & 10.0 & 3.9 & 10.0 & 62.2 \\ 2004-2005 & 3.5 & 9.5 & 3.5 & 9.5 & 64.6\end{array}$


